Check for updates

Cite this: RSC Adv., 2018, 8, 17279

\title{
Design, synthesis, and biological evaluation of AV6 derivatives as novel dual reactivators of latent HIV-1†
}

\author{
Mingtao Ao, $\dot{t}^{\mathrm{a}}$ Zhenrui Pan, $\dot{t}^{\mathrm{a}}$ Yuqing Qian, $\dot{t}^{\mathrm{a}}$ Bowen Tang, ${ }^{\mathrm{a}}$ Zeming Feng, (D) \\ Hua Fang, ${ }^{c}$ Zhen $\mathrm{Wu}{ }^{\mathrm{a}}$ Jingwei Chen, ${ }^{* b}$ Yuhua Xue ${ }^{\star a}$ and Meijuan Fang (DD ${ }^{* a}$
}

The "shock and kill" strategy might be a promising therapeutic approach for HIV/AIDS due to the existence of latent viral reservoirs. A major challenge of the "shock and kill" strategy arises from the general lack of clinically effective latency-reversing agents (LRAs). The 2-methylquinoline derivative, antiviral 6 (AV6) has been reported to induce latent HIV-1 expression and act synergistically with a HDAC inhibitor VA to reverse HIV latency. We report herein the design and identification of AV6 analogues which possess the zinc-binding group of HDAC inhibitors and have dual acting mechanism for the reactivation of HIV-1 from latency. Evaluation of compounds for the reactivation of HIV-1 latency identified two excellent active compounds $12 \mathrm{c}$ and $12 \mathrm{~d}$. Further bioassays revealed that these two compounds reactivated latent HIV-1 through dual mechanism, the inhibition of HDACs and NFAT-required for early HIV-1 gene expression. Additionally, it was found that 12c and 12d could reactivate HIV-1 transcription by releasing $\mathrm{P}-\mathrm{TEFb}$ from the inactive complex 7SK snRNP. At last, molecular docking identified their orientation and binding interactions at the active site of HDAC2. This experimental data suggests that $12 \mathrm{c}$ and $12 \mathrm{~d}$ can be served as effective HIV-1 LRAs which can be taken up for further studies.

Received 8th February 2018

Accepted 24th April 2018

DOI: $10.1039 / c 8 r a 01216 d$

rsc.li/rsc-advances transcription elongation factor $\mathrm{b}(\mathrm{P}-\mathrm{TEFb})$ activators and other unclassified HIV-1 latency-reversing agents. ${ }^{\text {14-18 }}$ HDAC inhibitors, such as valproic acid (VA), vorinostat (also known as SAHA), and panobinostat have been used in clinical trials in HIV. ${ }^{19-23}$ However, preclinical and clinical studies suggest that these LRAs which target a single mechanism involved in latency may not be efficient enough to reactivate latent HIV-1 in vivo. ${ }^{24-27}$ Hence, there is an urgent requirement of developing more effective latency-reversing interventions with a unique structure and effective mode of action.

Antiviral 6 (AV6, Fig. 1), a novel HIV-1 latency-reversing agent identified through high-throughput screening, has been reported to reproducibly activate latent HIV-1 in different cellbased latency model systems without causing general $\mathrm{T}$ cell proliferation or activation. ${ }^{28}$ Its activation is independent of the site of provirus integration, which complements the latency antagonist activity of HDAC inhibitor. For example, AV6 was demonstrated to act cooperatively with VA (a HDAC inhibitor) for enhanced induction of HIV-1 gene expression. ${ }^{28}$ This is a proof of concept showing that the combination of two or more inducers of HIV gene expression acting in accord via different mechanisms may produce a more potent reactivation effect. ${ }^{29,30}$ In this study, we design the AV6 analogues as LRAs with the goal of achieving HDACs inhibition. Key to the design is to identify the attachment appoint and the linker for the introduction of the essential active group of HDACs. Herein, we performed the chemical synthesis and biological evaluation of the first chemical series of AV6 analogues (series I) to determine the suitable $\dagger$ Electronic supplementary information (ESI) available. See DOI: $10.1039 / \mathrm{c} 8 \mathrm{ra} 01216 \mathrm{~d}$

$\$$ These authors contribute equally to this paper.
${ }^{a}$ School of Pharmaceutical Sciences, Fujian Provincial Key Laboratory of Innovative Drug Target Research, Xiamen University, South Xiang-An Road, Xiamen, 361102, China. E-mail: xueyuhua@xmu.edu.cn; fangmj@xтu.edu.cn; Fax: +86-592${ }^{b}$ Key Laboratory for Chemical Biology of Fujian Province, College of Chemistry and Chemical Engineering, Xiamen University, Xiamen 361005, China. E-mail: jwchen@ xтu.edu.cn

${ }^{c}$ The Third Institute of Oceanography of the State Oceanic Administration, Xiamen, 361005, China 


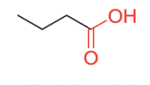

Butyric acid

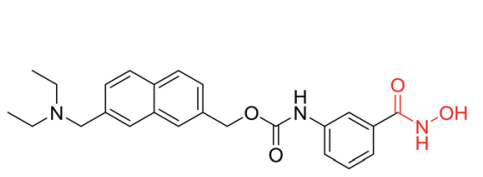

Givinostat (ITF2357)

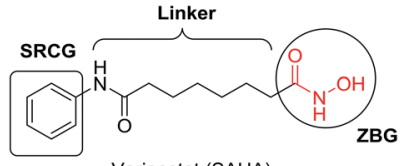

Vorinostat (SAHA)

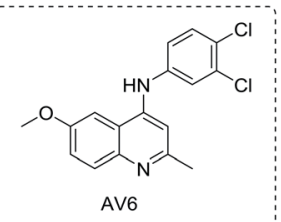

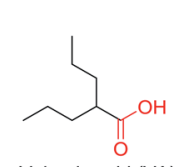

Valproic acid (VA)

Fig. 1 Several HIV reactivators. HDAC inhibitors: short-chain aliphatic acids (butyric acid and valproic acid), hydroxamic acids (vorinostat and givinostat). AV6: its target protein is not available now.

attachment appoint for the introduction of the functional group of HDAC inhibitor. Then, a linker optimization strategy was pursued to obtain effective LRAs bearing AV6 scaffold structure and the functional group of HDAC inhibitors. These new AV6 derivatives (series II) were evaluated for their reactivation of latent HIV. The most potent reactivators were then taken up to do further bioassays.

\section{Results and discussion}

\subsection{Design of the target compounds}

Multi-target drugs have emerged as an innovative therapeutic approach for many diseases due to their complex etiology and their multifactorial progression. ${ }^{31-33}$ AV6 and HDAC inhibitors have been validated as two inducers of HIV gene expression acting in accord via two different mechanisms. The $N$-phenylquinoline nucleus of AV6 is considered as 'Master Key Core' in many compounds aimed at different targets to bring out varied pharmacological properties. Besides, many HDACIs have been designed and synthesized as dual- or multi-targeted inhibitors for the cancer therapy, ${ }^{34}$ and the synergistic effect on the activation of latent provirus between VA (a carboxylate HDACi) and AV6 has been confirmed. ${ }^{28}$ Thus, we developed an idea that the introduction of the function groups of HDACis in the $N$-phenylquinoline structural scaffold of AV6 might also result in new compounds both targeting HDACs and with AV6 related active mechanism to generate more potent LRAs.

There are only three class I HDACs (HDAC 1, HDAC 2, HDAC 3) which are localized at the integrated HIV-1 LTR and are zincdependent deacetylasesas. ${ }^{\mathbf{1 4 , 3 5}}$ The classical pharmacophore for their HDACi consists of a zinc-binding group (ZBG), an appropriate linker and a surface recognition cap group. ${ }^{36}$ Generally, ZBG plays a significant role in the binding efficiency between HDACi and enzyme. Therefore, we intend to incorporate the essential active group ZBG of HDACis into the $\mathrm{N}$-phenylquinoline scaffold to generate new small molecule entities (AV6 analogues) which may display better potency to activate latent HIV-1. However, this is not a straight-forward procedure, and we must identify the appropriate common features, substitution sites, and then growing vectors.
We hypothesized that the substituents on the benzene or quinoline rings contained in AV6 structure might modulate the activation activity of the compound. Therefore, we initially designed series I derivatives (Fig. 2, compounds 7b-7B) of AV6 to evaluate the influence of different substituents and various attachment points on the activation activity and figure out the best site for the introduction of the functional group ZBG of the HDACis. There are various ZBGs for HDACi, such as hydroxamic acids, aminobenzamides, carboxylates (short-chain fatty acids), electrophilic ketones, thiols, mercaptoacetamides, and 3hydroxypyridin-2-thiones. Among all types of ZBGs, hydroxamic acid and carboxylate are common zinc ion chelating groups. So hydroxamic acid and carboxylates with different linker were subsequently incorporated into the suitable site of $N$-phenylquinoline nucleus in order to identify more potent novel LRAs (Fig. 2, series II). In this paper, we report the design, synthesis, and biological evaluation of AV6 analogues as novel LRAs with dual activated mechanism.

\subsection{Syntheses of the designed compounds}

The synthetic approaches for the two different series of target compounds are outlined in Scheme 1 and 2. Compounds 7a-7w were prepared according to a four-step procedure described previously and shown in Scheme $1 .^{37} p$-Anisidine was condensed with ethyl acetoacetate to form compound 2, which was cyclized in diphenyl ether affording 6-methoxy-4-hydroxy-2methylquinoline (3). The treatment of 3 with phosphorus oxychloride to provide the key intermediate 4-chloro-6-methoxy-2methylquinoline (4). ${ }^{38-40}$ Compounds $7 \mathbf{a}-7 \mathrm{e}$ could be easily obtained through the reaction of $\mathbf{4}$ with different nucleophilic amine derivatives in the presence of catalytic amount of $\mathrm{HCl}$. On the other hand, demethylation of 4 using $\mathrm{BBr}_{3}$ produced 4chloro-2-methylquinolin-6-ol (5). Alkylation of 5 with bromoethane or 2-bromopropane provided $\mathbf{6 a}$ or $\mathbf{6 b}$, and the reaction of halides (6a or $\mathbf{6 b}$ ) with corresponding amine derivatives produced compounds $7 \mathbf{f}-7 \mathbf{w}$ (Scheme 1). ${ }^{41,42}$

The designed products 9a-9e, 10a-10d, 11a-11d and 12a12d (series II) were synthesized according to the pathway shown

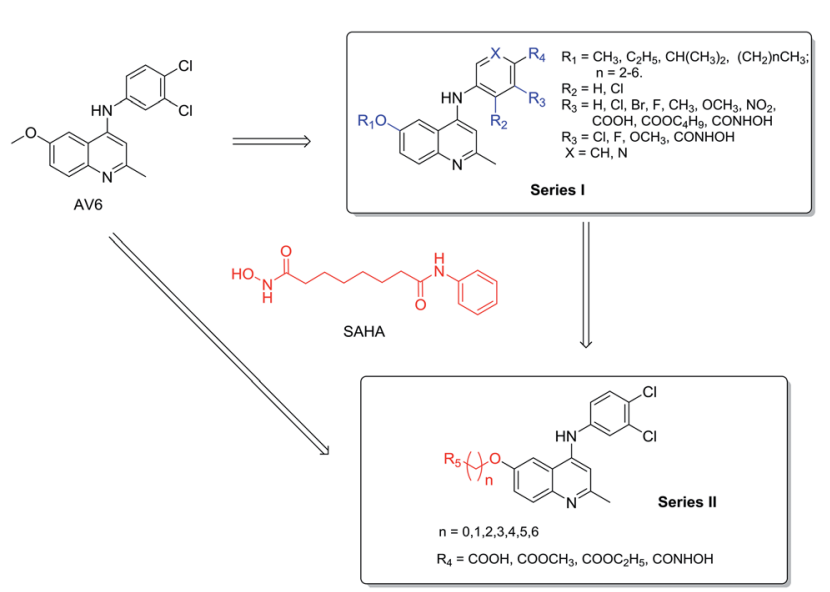

Fig. 2 Design of multi-targeted HIV activator based AV6 and HDAC inhibitors. 


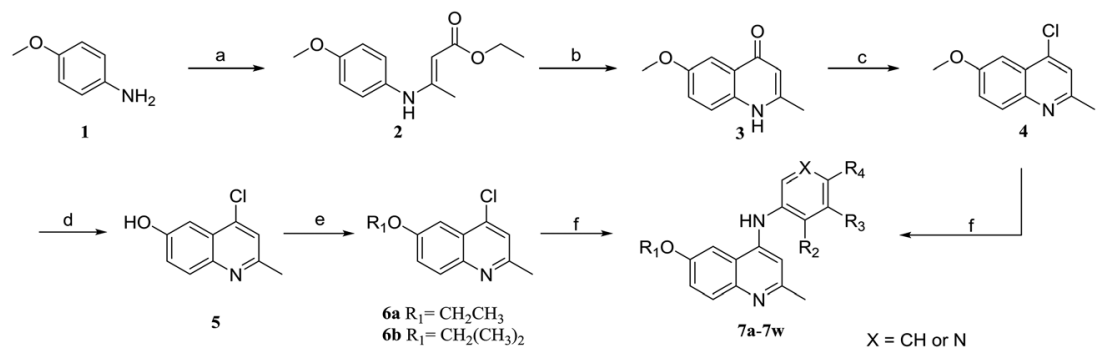

Scheme 1 Synthesis of 2-methyl- $N$-arylquinolin-4-amine 7a-7w. Reagents and conditions: (a) ethyl 3-oxobutanoate, EtOH, reflux, 4 h; (b) diphenyl ether, 1 h; (c) $\mathrm{POCl}_{3}, 120^{\circ} \mathrm{C}, 2$ h; (d) $\mathrm{BBr}_{3}, \mathrm{DCM}$, r.t., $2 \mathrm{~h}$; (e) $\mathrm{CH}_{3} \mathrm{CH}_{2} \mathrm{Br}$ or $\mathrm{CH}_{3} \mathrm{CHBrCH}_{3}, \mathrm{NaH}$, DMF, r.t., overnight; (f) substituted aromatic amines, butyl alcohol, conc. $\mathrm{HCl}, 120^{\circ} \mathrm{C}, 5 \mathrm{~h}$.

in Scheme 2. Demethylation on C-6 position of compound 7a gave corresponding $\mathrm{C} 6-\mathrm{OH}$ quinolone (8). Compound 8 converted to compounds $\mathbf{9 a - 9 e}$ and $\mathbf{1 0 a - 1 0 d}$ by alkylation of the C6-OH with appropriate alkyl halide and various lengths of ethyl or methyl bromoalkanoate, respectively. Carboxylic acid derivatives 11a-11d were finally obtained by the hydrolysis of esters 10a-10d. Conversion of esters 10a-10d to hydroxamic acids using freshly prepared hydroxylamine yielded the target compounds 12a-12d. ${ }^{43}$

The structures of the target compounds were confirmed with ${ }^{1} \mathrm{H}-\mathrm{NMR},{ }^{13} \mathrm{C}-\mathrm{NMR}$, and high-resolution mass spectrometry (HRMS).

\subsection{Biological evaluation}

2.3.1 Reactivation of latent HIV-1 gene expression in J-Lat A2 cells and structure-activity relationship. All target compounds were first evaluated for their activation of latent HIV-1 in J-Lat A2 cells, which contained an integrated $5^{\prime}$-LTRTat-Flag-iRES-EGFP-3'-LTR expression cassette that was normally silent, the enhanced green fluorescent protein (GFP) would be expressed under the control of $5^{\prime}$ LTR promoter upon activation. ${ }^{44}$ In this screening experiment, AV6 and SAHA were employed as positive controls. The results are presented in Tables 1-3. The structure-activity relationship (SAR) was further explored as described below.

At the first initial exploration, a variety of substituents and different attachment points at the benzene or quinoline rings contained in AV6 structure were examined. As shown in Table 1, compound 7a (AV6) with 6-methoxy and 3',4'-dichloro substitutions induced $57.0 \pm 1.2$ percent GFP production in J-Lat A2 cells at $10 \mu \mathrm{M}$. Upon comparison of the activities of 6-ethoxy derivatives $7 \mathbf{f}-7 \mathbf{j}$ and 6-isopropoxy derivatives 7o-7s with 6methoxy derivatives $7 \mathbf{a}-7 \mathbf{e}$, we found that the reactivation potency of the derivatives for latent HIV-1 is very sensitive to the type of $\mathrm{R}_{1}$ substituent. Compounds 7o-7s have no effect on HIV1 gene expression in J-Lat A2 cells, which suggest that the replacement of the methoxy group with the isoproyloxy group at C-6 position of quinoline ring is very detrimental for the reactivation potency of latent HIV-1. While in 6-ethoxy derivatives $\mathbf{7 f}-\mathbf{7 j}, \mathbf{7 f}$ exhibits good activity of latent HIV-1 reversing (47.3 \pm $3.3 \%$ at $10 \mu \mathrm{M})$, and compounds $7 \mathbf{g}-7 \mathbf{i}$ produce enhanced potency $(14.5-39.9 \%$ of the GFP expression at $10 \mu \mathrm{M})$ compared to corresponding 6-methoxy derivatives 7b-7d (with GFP\% values ranged from $2.1-8.3 \%$ at $10 \mu \mathrm{M}$ ). These results imply that the $\mathrm{C}-6$ position $\left(\mathrm{R}_{1}\right)$ of the quinoline ring may be a promising attachment point for the introducing of the ZBG groups by using the linear alkyl linker.

On the other hand, the replacement of $\mathrm{Cl}$ with linker groups $\left(\mathrm{CH}_{3}(\mathbf{7 d}\right.$ and $7 \mathbf{r})$ and $\mathrm{OCH}_{3}(\mathbf{7 e}, 7 \mathbf{j}, 7 \mathbf{s}$, and $\left.7 \mathbf{z})\right)$, ZBG groups $(\mathrm{COOH}$ (7l and $7 \mathbf{u})$, COOR ( $7 \mathbf{m}$ and $7 \mathbf{v})$, and $\mathrm{CONHOH}(\mathbf{n}$ and $7 \mathbf{y})$ ), or other groups $\left(\mathrm{NO}_{2}(7 \mathbf{k}\right.$, and $\left.7 \mathbf{t})\right)$ at the $\mathrm{C}-3^{\prime}\left(\mathrm{R}_{3}\right)$ and $\mathrm{C}-4^{\prime}$ $\left(\mathrm{R}_{4}\right)$ positions of phenyl ring leads to the disappearance of activity as shown in Table 1 . It indicates that $3^{\prime}, 4^{\prime}$-dichloro substitutions at the phenyl ring are essential for potent reactivation of latent HIV-1 gene expression. Moreover, compounds $7 \mathbf{A}(5.4 \pm 0.4 \%)$ and $7 \mathbf{B}(1.3 \pm 0.3 \%)$ in which the phenyl ring is

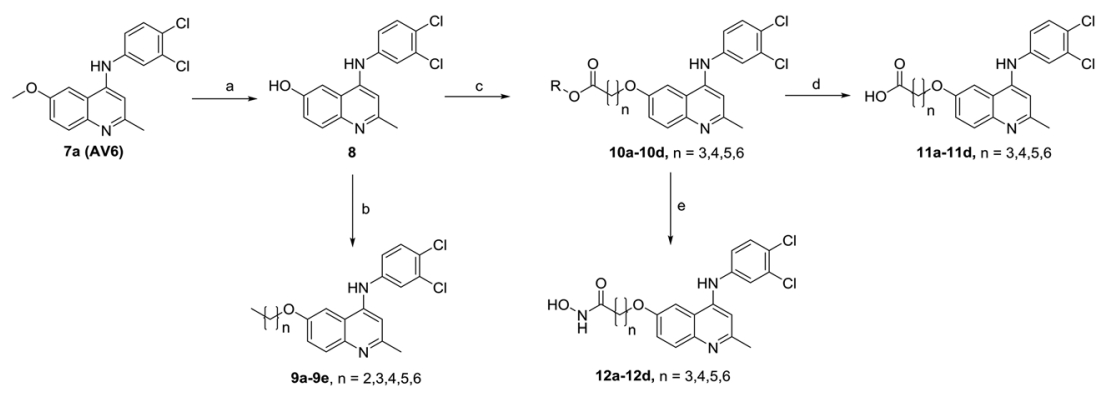

Scheme 2 Synthesis of 3-((4-((3,4-dichlorophenyl)amino)-2-methylquinolin-6-yl)oxy)-alkanoic acid/hydroxyl acid. Reagents and conditions:(a) $\mathrm{BBr}_{3}, \mathrm{DCM}$, r.t., 2 h; (b) appropriate alkyl halide, NaH, DMF, r.t., overnight; (c) ethyl or methyl bromoalkanoate, NaH, DMF, r.t., overnight; (d) EtOH, $40 \% \mathrm{NaOH}$ aqueous solution, $50{ }^{\circ} \mathrm{C}, 1 \mathrm{~h}$; (e) $\mathrm{NH}_{2} \mathrm{OH}, \mathrm{NaOH}, \mathrm{CH}_{3} \mathrm{OH}, 0^{\circ} \mathrm{C}$ to r.t. 
changed to the pyridine ring display weak or no induction of GFP expression in J-Lat A2 cells at $10 \mu \mathrm{M}$ in comparison with AV6/7a $(57.0 \pm 1.2 \%)$ and $7 f(47.3 \pm 3.3 \%)$, respectively. It implies that the phenyl ring is also essential for the activity. Additionally, $\mathbf{7 b}, \mathbf{7 f}-\mathbf{7 j}, \mathbf{7} \mathbf{m}$, and $\mathbf{7 A}$ also showed certain degree of activation effect (with GFP\% values $>2.0 \%$ ) at $5 \mu \mathrm{M}$. Among them, 6-ethoxy derivatives $7 \mathbf{f}-7 \mathbf{j}$ could reactivated latent HIV-1 in a dose-dependent manner better than 6-methoxy derivatives 7a-7e. Above all, the position C-6 $\left(\mathrm{R}_{1}\right)$ of quinoline ring might be better suited for the introduction of ZBG group than the positions $R_{3}$ and $R_{4}$ of benzene ring, and the $Z B G$ group would like to be introduced in $\mathrm{R}_{1}$ position by using linear linker.

To explore the effect of chain length of linear linker on activity, a series of ether analogues of AV6 (9a-9e) with 3-7 carbons of $n$-alkyl chain at the C- 6 position of the quinolone ring was generated and their reactivation of latent HIV-1 gene expression was evaluated. As shown in Table 2, all ether analogues of AV6 (9a-9e) with 3-7 carbons of linear alkyl chain retained potent activities in the induction of GFP expression in
$\mathrm{J}$-Lat A2 cells at $10 \mu \mathrm{M}(19.7 \pm 0.7 \%-32.4 \pm 2.9 \%)$ and $5 \mu \mathrm{M}(11.1$ $\pm 1.8 \%-29.1 \pm 2.2 \%$ ). It was further confirmed that together with the oxygen connection, the straight alkyl chain could be used as linear linker for the introduction of ZBG groups at 6position of quinolone ring.

Finally, we investigated the effect of various ZBG groups with linear alky linker connected to the C-6 position of the quinoline ring on latent $\mathrm{HIV}-1$ reactivation. Different $\mathrm{ZBG}$ groups $\left(\mathrm{COOC}_{2} \mathrm{H}_{5}, \mathrm{COOH}\right.$, and $\left.\mathrm{CONHOH}\right)$ were introduced at the terminal of the straight alkyl chain on 6-position of quinolone ring, and another three series of AV6 analogues (10a-10d, 11a11d, and 12a-12d) were generated and analyzed. Among these new derivatives with various ZBG groups, compounds 10a-10d (carboxylates) and 11a-11d (carboxylic acids) were either weakly active or completely inactive at tested concentrations (Table 3). Compounds with hydroxamic acid side chain showed varying degrees of potency to reverse HIV latency (12b-12d), except for compound 12a. Compounds $12 \mathrm{c}$ and $\mathbf{1 2 d}$ exerted a remarkable improvement in the latent $\mathrm{HIV}-1$ reactivation activity, inducing

Table 1 Reactivation of latent HIV-1 gene expression by the indicated quinolines in J-Lat A2 cells ${ }^{a}$

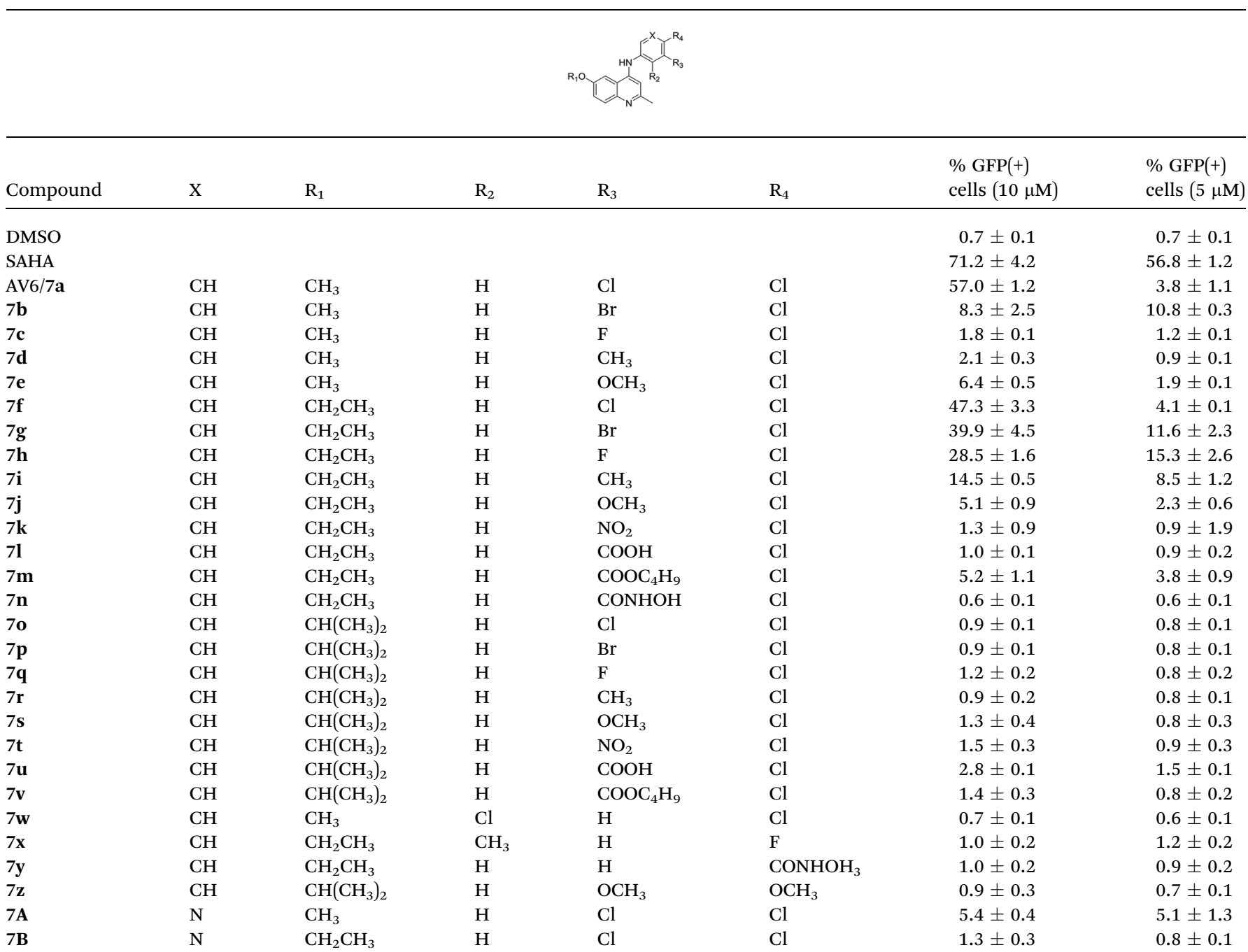

${ }^{a}$ Data are presented as mean \pm SD of at least three independent experiments performed in triplicate. Cells were treated with the indicated compounds at $5,10 \mu \mathrm{M}$ for $24 \mathrm{~h}$. The expression of GFP were evaluated by FACS. 
Table 2 Reactivation of latent HIV-1 gene expression by the indicated quinolines in J-Lat A2 cells ${ }^{a}$

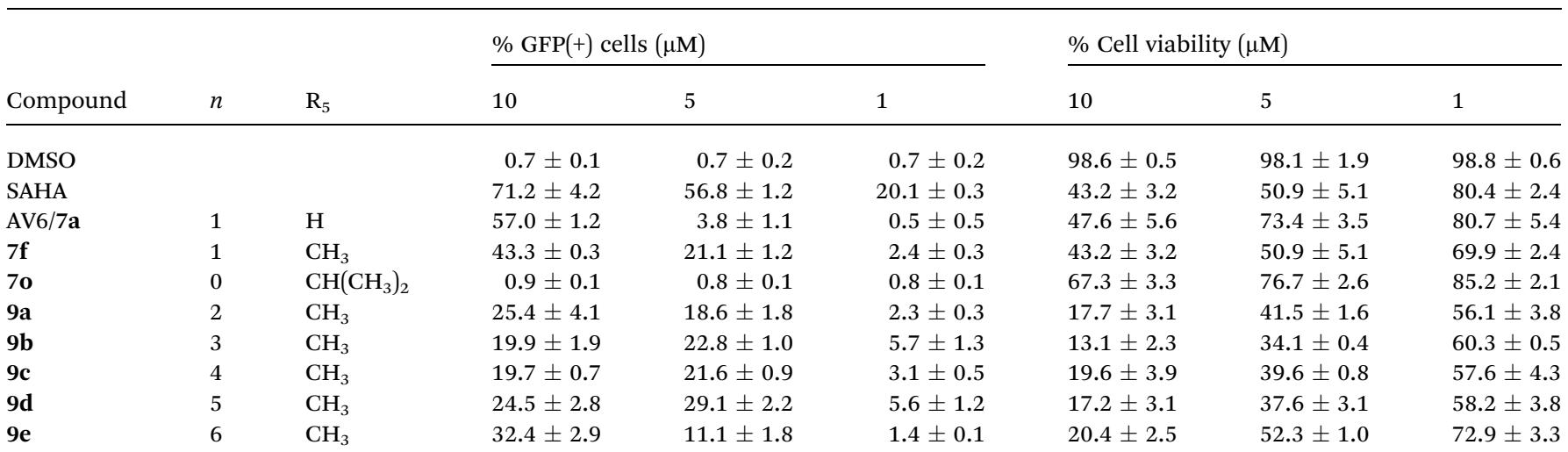

${ }^{a}$ Data are presented as mean $\pm \mathrm{SD}$ of at least three independent experiments performed in triplicate. Cells were treated with the indicated compounds at 1, 5, $10 \mu \mathrm{m}$ for $24 \mathrm{~h}$. The expression of GFP were evaluated by FACS.

$39.7 \pm 4.1 \%$ and $49.9 \pm 3.5 \%$ GFP production in J-Lat A2 cells at $1 \mu \mathrm{M}$, respectively. However, they displayed slightly higher toxicity than SAHA and AV6 according to the cell viability (Table 2 ). In this experiment, we also observed that the length of the alkyl linker with oxygen bonded connection at the C-6 position had an important effect on the activity. For example, for compounds that had the same terminal basic group - $\mathrm{CONHOH}$, the latency-reversing activity of $12 \mathrm{c}(n=5)$ and $\mathbf{1 2 d}(n=6)$ were much better than that of $\mathbf{1 2 a}(n=3)$ and $\mathbf{1 2} \mathbf{b}(n=4)$. These results indicate that the length of the linear alkyl linker $(n)$ and its terminal basic group $\left(\mathrm{R}_{5}\right)$ have important impacts on the compounds regarding their binding activities.

Among all these AV6 analogues, 12c and 12d showed the most optimal properties in terms of its efficient latencyreversing activity and displayed relatively mild cytotoxicity, thus they were selected for further bioassays as outlined below.

2.3.2 Compounds 12c and 12d promote HIV-1 LTR-driven GFP expression in different latency cell models. When J-Lat A2 cells were treated with different amounts of AV6, SAHA, 12c, and 12d, the percentage of GFP-positive cells induced by

Table 3 Reactivation of latent HIV-1 gene expression by the indicated quinolines in J-Lat A2 cells ${ }^{a}$

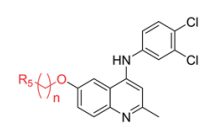

\begin{tabular}{|c|c|c|c|c|c|c|c|c|}
\hline \multirow[b]{2}{*}{ Compound } & \multirow[b]{2}{*}{$n$} & \multirow[b]{2}{*}{$\mathrm{R}_{5}$} & \multicolumn{3}{|c|}{$\% \operatorname{GFP}(+)$ cells $(\mu \mathrm{M})$} & \multicolumn{3}{|c|}{$\%$ Cell viability $(\mu \mathrm{M})$} \\
\hline & & & 10 & 5 & 1 & 10 & 5 & 1 \\
\hline DMSO & & & $0.7 \pm 0.1$ & $0.7 \pm 0.2$ & $0.7 \pm 0.2$ & $98.6 \pm 0.5$ & $98.1 \pm 1.9$ & $98.8 \pm 0.6$ \\
\hline SAHA & & & $71.2 \pm 4.2$ & $56.8 \pm 1.2$ & $20.1 \pm 0.3$ & $43.2 \pm 3.2$ & $50.9 \pm 5.1$ & $80.4 \pm 2.4$ \\
\hline AV6/7a & 1 & $\mathrm{H}$ & $57.0 \pm 1.2$ & $3.8 \pm 1.1$ & $0.5 \pm 0.5$ & $47.6 \pm 5.6$ & $73.4 \pm 3.5$ & $80.7 \pm 5.4$ \\
\hline $10 a$ & 3 & $\mathrm{COOC}_{2} \mathrm{H}_{5}$ & $3.3 \pm 0.2$ & $3.2 \pm 0.5$ & $0.8 \pm 0.1$ & $94.3 \pm 2.5$ & $97.1 \pm 2.9$ & $86.3 \pm 3.4$ \\
\hline $10 \mathrm{~b}$ & 4 & $\mathrm{COOCH}_{3}$ & $1.6 \pm 0.7$ & $1.4 \pm 0.4$ & $0.9 \pm 0.2$ & $92.6 \pm 3.4$ & $95.6 \pm 3.7$ & $85.8 \pm 4.7$ \\
\hline $10 \mathrm{c}$ & 5 & $\mathrm{COOC}_{2} \mathrm{H}_{5}$ & $0.7 \pm 0.2$ & $1.5 \pm 0.5$ & $0.9 \pm 0.2$ & $95.4 \pm 3.3$ & $97.3 \pm 2.9$ & $87.0 \pm 3.1$ \\
\hline 10d & 6 & $\mathrm{COOCH}_{3}$ & $0.9 \pm 0.2$ & $1.7 \pm 0.3$ & $0.8 \pm 0.1$ & $96.6 \pm 3.2$ & $96.7 \pm 2.5$ & $86.1 \pm 2.3$ \\
\hline $11 a$ & 3 & $\mathrm{COOH}$ & $0.6 \pm 0.1$ & $0.7 \pm 0.2$ & $0.9 \pm 0.1$ & $97.6 \pm 2.8$ & $97.1 \pm 1.9$ & $76.8 \pm 2.6$ \\
\hline $11 b$ & 4 & $\mathrm{COOH}$ & $1.1 \pm 0.1$ & $1.2 \pm 0.1$ & $0.7 \pm 0.1$ & $95.6 \pm 2.4$ & $97.2 \pm 3.0$ & $83.7 \pm 3.5$ \\
\hline $11 \mathrm{c}$ & 5 & $\mathrm{COOH}$ & $0.8 \pm 0.1$ & $1.1 \pm 0.1$ & $0.7 \pm 0.2$ & $94.6 \pm 2.8$ & $95.4 \pm 2.9$ & $94.9 \pm 0.6$ \\
\hline 11d & 6 & $\mathrm{COOH}$ & $1.0 \pm 0.1$ & $1.1 \pm 0.1$ & $0.9 \pm 0.2$ & $97.6 \pm 3.5$ & $96.3 \pm 1.9$ & $97.8 \pm 1.6$ \\
\hline $12 a$ & 3 & $\mathrm{CONHOH}$ & $2.7 \pm 0.1$ & $1.3 \pm 0.9$ & $1.1 \pm 0.3$ & $85.7 \pm 4.2$ & $94.2 \pm 1.1$ & $95.3 \pm 3.1$ \\
\hline $12 b$ & 4 & CONHOH & $19.7 \pm 2.1$ & $2.8 \pm 1.7$ & $0.7 \pm 0.6$ & $54.1 \pm 3.7$ & $89.5 \pm 4.2$ & $89.3 \pm 4.8$ \\
\hline $12 \mathrm{c}$ & 5 & $\mathrm{CONHOH}$ & $87.2 \pm 2.0$ & $81.5 \pm 1.5$ & $39.7 \pm 4.1$ & $44.1 \pm 3.4$ & $49.8 \pm 3.9$ & $44.2 \pm 3.6$ \\
\hline $12 d$ & 6 & $\mathrm{CONHOH}$ & $84.9 \pm 3.5$ & $77.1 \pm 2.4$ & $49.9 \pm 3.5$ & $38.6 \pm 3.1$ & $32.7 \pm 3.4$ & $39.1 \pm 2.9$ \\
\hline
\end{tabular}

${ }^{a}$ Data are presented as mean \pm SD of at least three independent experiments performed in triplicate. Cells were treated with the indicated compounds at 1, 5, $10 \mu \mathrm{m}$ for $24 \mathrm{~h}$. The expression of GFP were evaluated by FACS. 
(A)

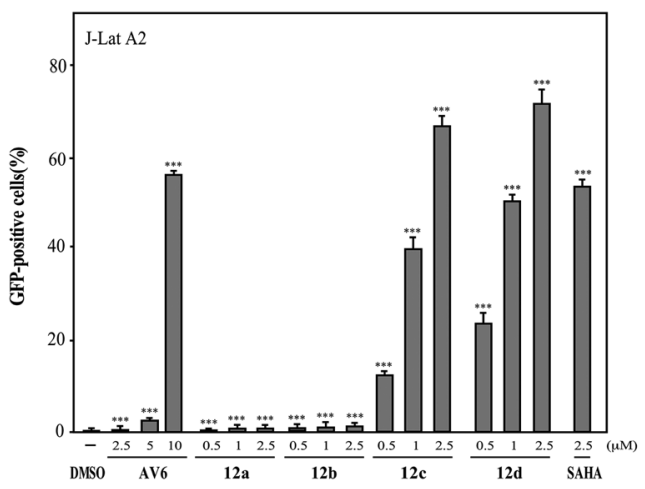

(B)

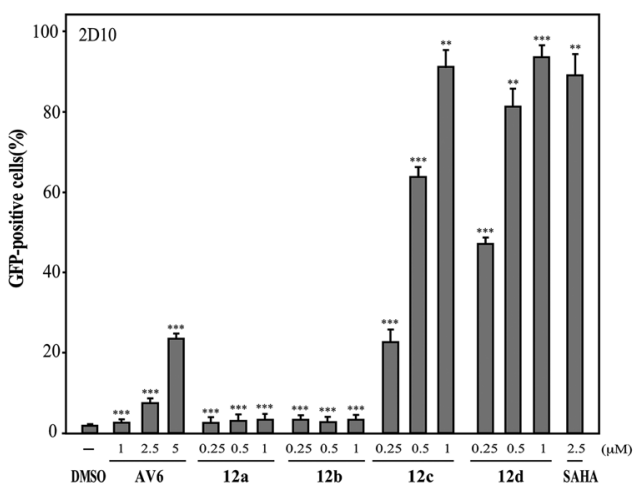

(C)

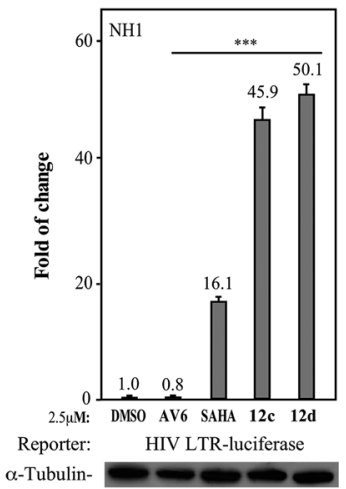

(D)

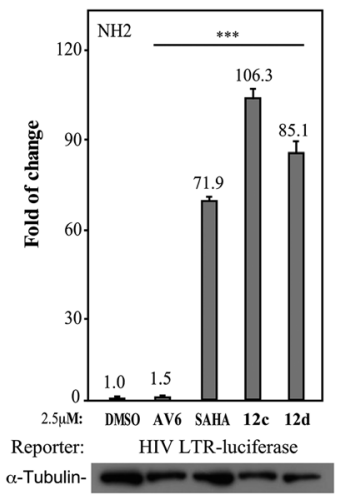

Fig. 3 HIV latency can be reversed by 12c-12d in different latency cell models. (A) J-Lat A2 cells, (B) 2D10 cells, (C) the HeLa-based NH1 cells. (D) The $\mathrm{NH} 2$ cells expressing Tat. All tested cells were treated with $0.1 \%$ DMSO or the indicated concentrations of the drugs (12c, 12d, SAHA and AV6) for $24 \mathrm{~h}$. The expression of GFP for tested J-Lat A2 and 2D10 cells was measured by FACS. Whole cell extracts for tested NH1 and NH2 cells were prepared and examined for the luciferase activities. The error bars in all panels represent mean \pm SD based on at least three independent experiments. The $P$ value was defined as $* * p<0.01$, and $* * * p<0.001 \mathrm{vs}$. control.

12c and 12d increased in a dose-dependent manner (Fig. 3(A)). The stimulatory effect to reactivate latent HIV-1 was also confirmed in 2D10 cell line (Fig. 3(B)), which is another Jurkatbased post-integrative latency model that harbors almost the complete HIV genome except for encoding a partially attenuated Tat variant $\mathrm{H} 13 \mathrm{~L}$ and the nef gene that is replaced by the GFP-coding sequence. ${ }^{45}$ In order to know whether compounds 12c and 12d activated latent HIV-1 depend on viral $5^{\prime}$-LTR, we additionally tested the effect of AV6, SAHA, 12c, and 12d at 2.5 $\mu \mathrm{M}$ in NH1 and NH2 cells, which is a pair of HeLa-based isogenic cells line and both of which contain an integrated HIV-1 5'-LTR-luciferase reporter gene but only the latter stably expresses HIV-1 Tat. ${ }^{\mathbf{4 6 , 4 7}}$ As shown in Fig. 3(C) and (D), AV6 did not shown any activation effect, while compounds 12c and 12d induced a significant increase in luciferase activity in both NH1 and $\mathrm{NH} 2$, which is much better than SAHA at the same concentration $(2.5 \mu \mathrm{M})$. Taken together, these results suggest that compounds 12c and 12d promote HIV-1 LTR-driven GFP expression in different latency cell models and give us a hint that previous design of AV6 analogues is reasonable.

2.3.3 Dual mechanism of $12 \mathrm{c}$ for the reactivation of latent HIV-1. Compounds 12c and 12d were derived from AV6 and designed by incorporating histone deacetylase (HDAC) inhibitory functionality into the pharmacophore of AV6, as dualacting HIV LRAs. Previous studies have reported that AV6 acts in part at a posttranscriptional level and synergizes with the HDAC inhibitor valproic acid to reverse HIV latency. ${ }^{28}$ So we first verified that the synergism can also be found between AV6 and SAHA in J-Lat A2 cells. As shown in Fig. 4(A), the combination of $5 \mu \mathrm{M}$ AV6 and $1 \mu \mathrm{M}$ SAHA produced $49.0 \pm 3.2$ of $\%$ GFP expression, which is greater than the simple sum $(23.9 \pm 1.4)$ of the effects produced by $5 \mu \mathrm{M}$ AV6 $(3.8 \pm 1.1)$ and $1 \mu \mathrm{M}$ SAHA $(20.1 \pm 0.3)$. The efficacy is believed to be a result of the synergy between AV6 and SAHA. However, there is no synergy between 12c and AV6/SAHA (Fig. 4(A)). For example, the combination of $1 \mu \mathrm{M}$ SAHA and $1 \mu \mathrm{M}$ 12c, which produced $58.4 \pm 3.8$ of $\%$ GFP expression, almost have the same effect on the activation of latency HIV-1 with the simple sum $(59.8 \pm 4.4)$ of $1 \mu \mathrm{M}$ SAHA $(20.1 \pm 0.3)$ and $1 \mu \mathrm{M} \mathrm{12c}(39.7 \pm 4.1)$. Similarly, the combination of $5 \mu \mathrm{M}$ AV6 and $1 \mu \mathrm{M} 12 \mathrm{c}$ produced $44.5 \pm 2.9$ of $\%$ GFP expression which is almost the same as the simple sum (43.5 \pm $5.2)$ of $5 \mu \mathrm{M}$ AV6 $(3.8 \pm 1.1)$ and $1 \mu \mathrm{M} \mathrm{12c}(39.7 \pm 4.1)$. From these findings, we can assume that 12c may have similar 
(A)

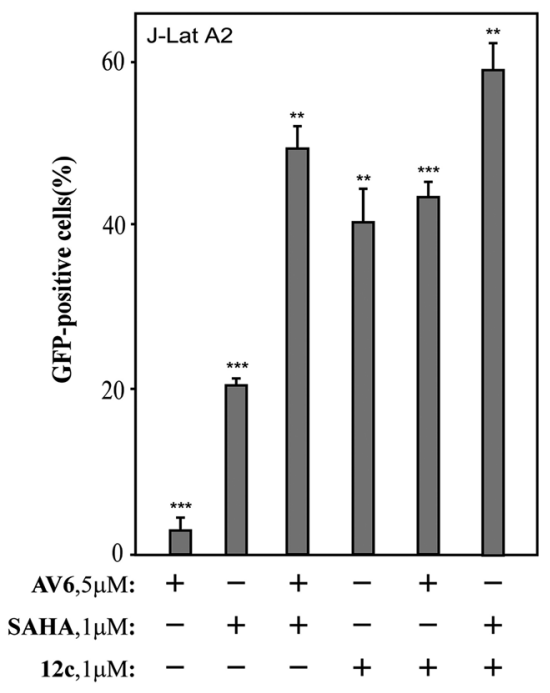

(B)

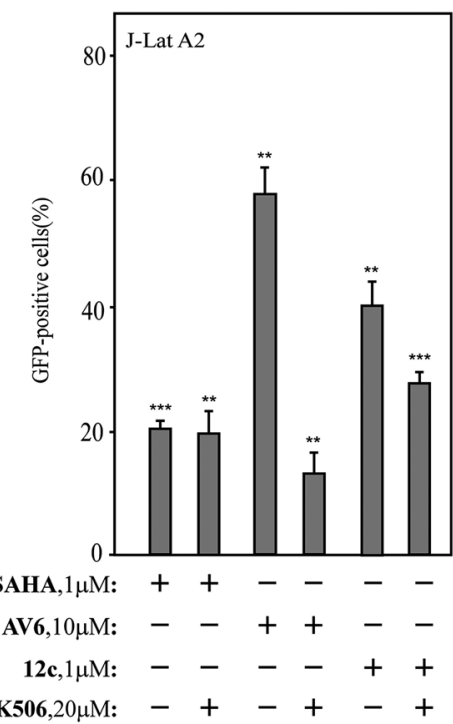

Fig. 4 12c retains the reactivation mechanism of AV6. (A) J-Lat A2 cells were treated with AV6, SAHA, 12c alone, or in combination for $24 \mathrm{~h}$, and then analyzed by flow cytometry to determine the percentages of GFP(+) cells. (B) J-Lat A2 cells were treated with SAHA, AV6 or $12 \mathrm{c}$ for $24 \mathrm{~h}$, in the presence or absence of the calcineurin inhibitor FK506 $(20 \mu \mathrm{M})$. The percentages of GFP $(+)$ cells were evaluated by FACS and plotted. Results shown are the means \pm SD from three independent experiments. The $P$ value was defined as $* * p<0.01$, and *** $p<0.001$ vs. control.

mechanisms with AV6 and SAHA to induce HIV-1 latency reversal.

2.3.3.1 Activate latent HIV-1 via the NFAT-required mechanism. It was reported that AV6 requires nuclear factor of activated T-cells (NFAT) for inducing latent HIV-1 expression, but not SAHA. The function of NFAT is regulated by calcineurin $(\mathrm{CaN})$, a calcium and calmodulin dependent serine/threonine protein phosphatase, which activates the $\mathrm{T}$ cells of the immune system and can be blocked by its inhibitors. ${ }^{48}$ To determine whether NFAT is involved in the reversal of HIV latency by 12c, J-Lat A2 cells were pre-treated with the calcineurin inhibitor FK506 before the incubation with 12c. As illustrated in Fig. 4(B), the calcineurin inhibitor FK506 could block AV6-dependent viral expression but did not affect the reactivation of HIV latency induced by SAHA. The reactivation of
HIV latency induced by 12c was decreased after pre-treated with FK506, so FK506 also did block 12c-dependent viral gene expression to some extent. These results suggest that 12c retains the reactivation mechanism of AV6, which requires NFAT for early HIV-1 gene expression. While compound 12c is not as sensitive to FK506 as AV6 is, it indicates that 12c may activate latent HIV-1 from latent reservoirs as a HDACs inhibitor.

2.3.3.2 Activate latent $H I V-1$ as histone deacetylase (HDAC) inhibitors. It is well known that inhibition of HDACs is sufficient to reactivate a fraction of latent HIV in a variety of experimental systems. Histone acetylation consists of the addition of an acetyl group to the $\varepsilon$-amino group of lysine residues. Histone lysine acetylation, on lysine 9 or 14 of histone H3 (H3K9, H3K14) or on lysine 16 of histone H4 (H4K16), is generally associated with active gene transcription. ${ }^{15,21}$ Thus, we
(A)
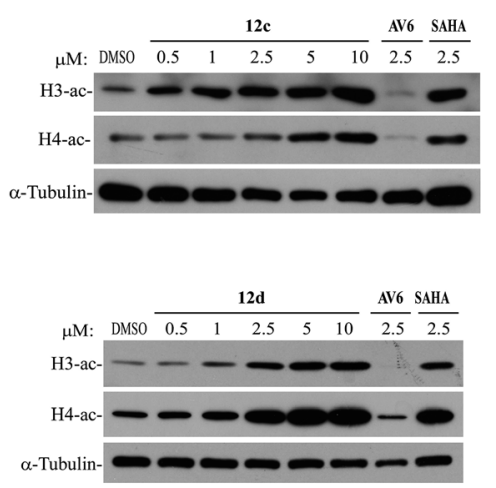

(B)
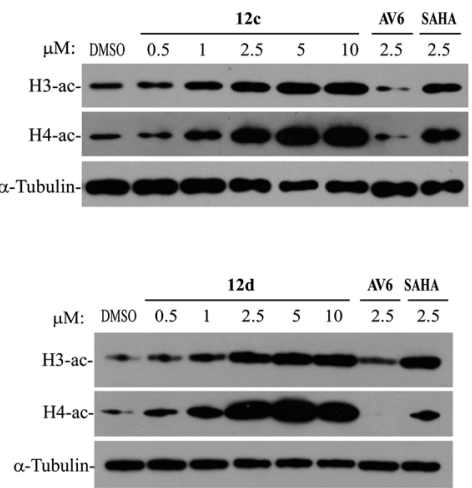

(C)
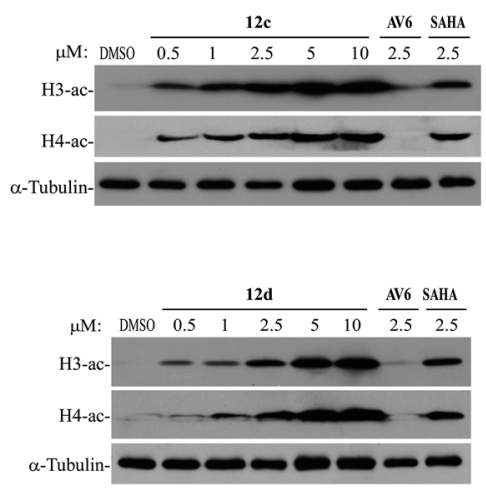

Fig. 5 Western blotting analysis of the acetylation levels of histones $\mathrm{H} 3$ and $\mathrm{H} 4$ in A549 cells (A), HeLa cells (B) and J-Lat A2 cells (C) after $12 \mathrm{c}$ and $12 \mathrm{~d}$ treatment respectively for $24 \mathrm{~h}$. 


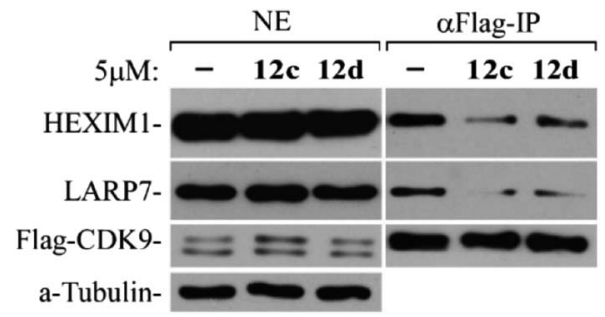

Fig. 6 The HeLa-based F1C2 cells stably expressing the Flag-tagged CDK9 were treated with 12c, 12d, or DMSO for $24 \mathrm{~h}$. Nuclear extracts (NE) and anti-Flag immunoprecipitates (IP) derived from NE were analyzed by western blotting for the indicated proteins.

examined whether compounds $\mathbf{1 2 c}$ and $\mathbf{1 2 d}$ with the functional group ZBG of HDACs inhibitors also inhibited intracellular even nuclear HDACs by monitoring the acetylation levels of histones $\mathrm{H} 3$ and $\mathrm{H} 4$ in HeLa and A549, and J-Lat A2 cell lines. In this assay, SAHA (a clinically approved pan-HDAC inhibitor) was used as positive control, DMSO and AV6 were used as negative controls. It was found that after the treatment of compounds 12c and 12d, the acetylation of histone $\mathrm{H} 3$ and $\mathrm{H} 4$ was significantly up regulated in a dose-dependent manner, whereas AV6 which lacked HDAC inhibition activity was not effect on the acetylation levels of histones $\mathrm{H} 3$ and $\mathrm{H} 4$ (Fig. 5). It indicated that the right introduction of a $\mathrm{ZBG}(-\mathrm{CONHOH})$ in the AV6 scaffold generated two excellent LRAs 12c and 12d, which possessed strong activity on HDACs inhibition to induce HIV-1 latency reversal.

2.3.4 Compounds $12 \mathrm{c}$ and $12 \mathrm{~d}$ release $\mathrm{P}$-TEFb from the inactive complex 7SK snRNP. Positive transcription elongation factor $b$ (P-TEFb), which is composed of CDK9 and CycT1, is a critical component of the cellular transcriptional machinery that is required for the elongation of HIV transcription. ${ }^{49,50}$ In latently HIV infected cells, most of the cellular P-TEFb are sequestered in inactive complex 7SK snRNP. Besides P-TEFb, this complex also contains the 7SK snRNA that acts as a molecular scaffold to hold the complex together and the protein HEXIM1 and LARP7, which inhibits the CDK9 kinase activity and binds to the $3^{\prime}$ end of 7SK SnRNA, respectively. ${ }^{16,46,51-55}$ Releasing active P-TEFb from 7SK snRNP should be an excellent strategy to activate viral replication in these cells. $^{49}$ To determine whether $12 \mathrm{c}$ and $\mathbf{1 2 d}$ are capable of inducing P-TEFb's dissociation from 7SK snRNP, an anti-Flag immunoprecipitation was performed in the HeLa-based F1C2 cells which stably express the Flag-tagged CDK9 (CDK9Flag), ${ }^{\mathbf{5 1 , 5 6}}$ to examine the association of CDK9 with two signature 7SK snRNP components HEXIM1 and LARP7. ${ }^{57}$ Using DMSO as a negative control, it was found that 12c and 12d markedly reduced the amounts of HEXIM1 and LARP7 bound to the immunoprecipitated CDK9-Flag (Fig. 6). It indicated that 12c

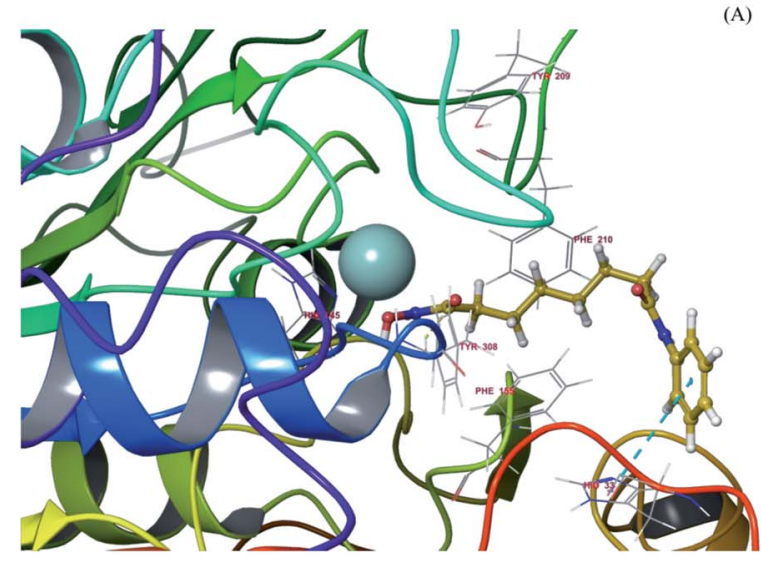

(C)

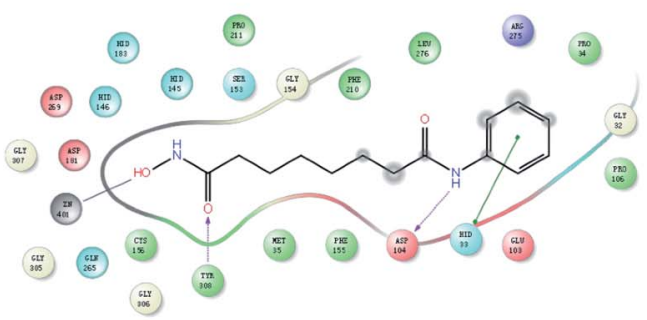

(A)

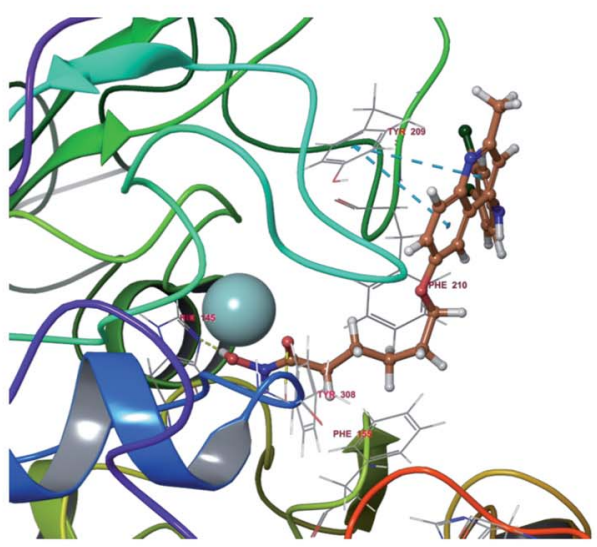

(B)

(D)

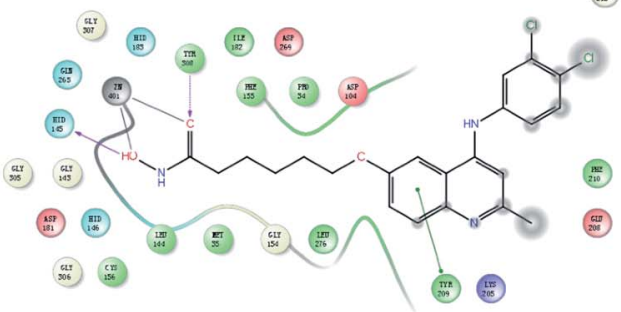

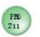

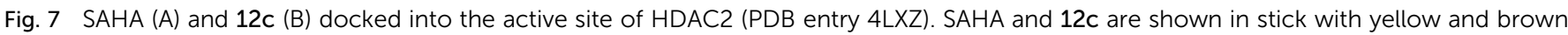

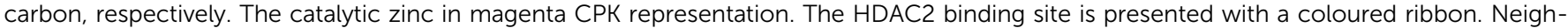

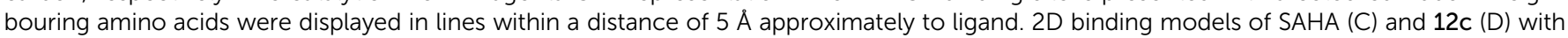

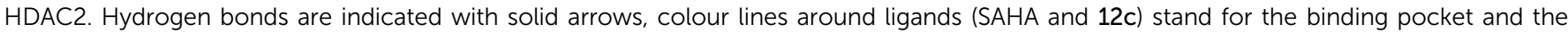

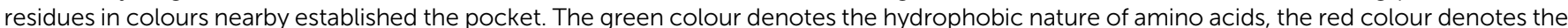

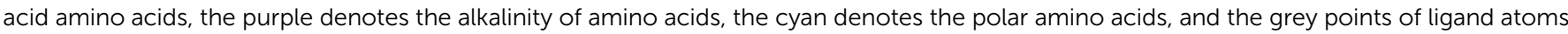
denotes the solvent accessibility. 
and 12d were able to reactivate HIV-1 transcription by releasing $\mathrm{P}-\mathrm{TEFb}$ from the inactive complex 7SK snRNP.

\subsection{Molecular docking study of compound $12 \mathrm{c}$ and $12 \mathrm{~d}$ to HDAC2}

SAHA achieves broad HDAC inhibitor activity through recognition of conserved structural features within this family of enzymes. We performed molecular docking study in the HDAC2 to determine the binding mode for AV6 analogues and study the key interactions between AV6 analogues and HDAC2. The X-ray protein structure of the human HDAC2 co-crystallized with SAHA in the ligand binding pocket (PDB code: 4LXZ) was selected to run the docking calculations. Re-docking was first carried out with the co-crystal ligand (SAHA) into the binding site of HDAC2 and compared with the co-crystal pose (4LXZ) to assess the docking protocol in this study. The RMSD value of redocked SAHA refereeing with the co-crystal pose is $0.773 \AA$ (see Fig. S1 of the ESI $\dagger$ ), which indicated our docking results were reliable as the success rate of docking is usually judged using the RMSD value lesser than $2.0 \AA$. Then, we performed the docking analysis of 12c binding to HDAC2. Molecular docking study indicated that the docking score of 12c $\left(-5.949 \mathrm{kcal} \mathrm{mol}^{-1}\right)$ beyond 2-fold to SAHA $\left(-2.759 \mathrm{kcal} \mathrm{mol}^{-1}\right)$. Comparison of the binding poses of SAHA and $12 \mathrm{c}$ in the active site of HDAC2 (Fig. 7) shows that the ZBGs of 12c and SAHA both form interactions with the zinc ion and TYR308, but only the OH group of 12c's ZBG establishes an additional hydrogen bond which interacted with the side chain of residue HID145 (distance: $1.96 \AA$ ). In addition, the interaction between the surface of binding site and their cap groups was apparently different. The cap group of SAHA phenyl group has $\pi-\pi$ stacking interaction with residue HID33, while for 12c binding mode the quinolone core formed a key $\pi-\pi$ stacking interaction with residue TYR209. These findings might lead to the better docking score for 12c than SAHA. In this work, molecular model of HDAC2 in complex with 12d was also constructed. It was found that compound 12d showed a similar binding mode with $12 \mathrm{c}$ (see Fig. S2 of the ESI†).

\section{Conclusion}

In summary, series of 2-methylquinolin-4-amine compound were synthesized and their ability to activate latent HIV-1 were evaluated in J-Lat A2 cells. Among all synthesized compounds, compound 12c and 12d exhibited excellent potency to reverse HIV latency. Compared with the obviously a lot of synergy between SAHA and AV6, no cooperative effect was observed using the combination of 12c and AV6 for the reactivation of latent HIV-1 gene expression, and to some extent the 12cdependent viral gene expression was blocked by the calcineurin inhibitor FK506 which did block AV6-dependent mRNA expression. ${ }^{28}$ These data indicate that $12 \mathrm{c}$ retains the reactivation mechanism of AV6, which requires NFAT for early HIV1 gene expression. On the other hand, the western blotting clearly showed that both in the HepG2 cells and A549 cells treated with 12c and 12d, the lysine acetylation of histone H3 and histone $\mathrm{H} 4$ increased in a dose-dependent manner. This study implies that 12c and 12d also act as HDAC inhibitors to reactivate HIV-1 transcription. Positive transcription elongation factorb (P-TEFb) is a critical component of the cellular transcriptional machinery that is required for the elongation of HIV transcription. In this work, the co-immunoprecipitation assay confirmed that 12c and 12d were able to release P-TEFb from the inactive complex 7SK snRNP to activate HIV transcription. Molecular docking yielded binding modes for compounds 12c and 12d with the similar metal coordination with $\mathrm{ZN}^{2+}$ as well as SAHA, and its larger cap group quinoline core increased the interactions with HDAC2 and turned in the opposite direction from the cap group of SAHA. All these results proved the potential of $12 \mathrm{c}$ and $\mathbf{1 2 d}$ as novel dual reactivator of latent HIV1. However, further studies are required to determine their roles in reactivating latent HIV-1.

\section{Experimental section}

\subsection{Chemistry}

All reagents were commercial available and used without further purification, unless otherwise indicated. Reactions, which required the use of anhydrous, inert atmosphere techniques, were carried out under an atmosphere of nitrogen. Reactions were magnetically stirred and monitored by thinlayer chromatography (TLC) on Merck silica gel 60F-254 by fluorescence. ${ }^{1} \mathrm{H}-\mathrm{NMR}$ and ${ }^{13} \mathrm{C}-\mathrm{NMR}$ spectra were obtained using a Bruker (Bruker Biospin, Zug, Switzerland) AV2600 Ultrashield spectrometer at 600 and $150 \mathrm{MHz}$, respectively. Chemical shifts were reported in parts per million (ppm) relative to tetramethylsilane (TMS) as an internal standard. Multiplicities were abbreviated as follows: single (s), doublet (d), doublet of doublets (dd), doublet-triplet $(\mathrm{dt})$, triplet $(\mathrm{t})$, triplettriplet (tt), triplet-doublet (td), quartet (q), quartet-doublet (qd), multiplet $(\mathrm{m})$, and broad signal (brs). High-resolution mass spectral (HRMS) data were acquired on a Q Exactive. Melting. points were measured on a SGW X-4 micro-melting point spectrometer and were uncorrected. The purities of synthesized compounds were assessed by high performance liquid chromatography (HPLC) with a COSMOSIL C18-MS-II column $(250 \mathrm{~mm} \times 4.6 \mathrm{~mm}$ i.d., $5 \mu \mathrm{m})$. The HPLC analysis was performed on an Agilent Technologies 1100 Series HPLC system. The mobile phase was methanol (A) and water (B) in a linear gradient mode as follows: (A) from $5 \%$ to $100 \%$ and (B) from $95 \%$ to $0 \%$ during $0-30 \mathrm{~min}$. The flow rate was $1 \mathrm{~mL} \mathrm{~min}^{-1}$, and the detection wavelengths were $254 \mathrm{~nm}$ and $280 \mathrm{~nm}$.

4.1.1 Ethyl 3-((4-methoxyphenyl)imino)butanoate (2). A mixture of $p$-anisidine (1) $(406.3 \mathrm{mmol}, 50.0 \mathrm{~g})$, ethyl acetoacetate $(487.2 \mathrm{mmol}, 62.0 \mathrm{~mL})$, anhydrous magnesium sulfate $(291.0 \mathrm{mmol}, 35.1 \mathrm{~g})$ and acetic acid $(2.0 \mathrm{~mL})$ in ethanol $(100.0$ $\mathrm{mL}$ ) was refluxed at $90{ }^{\circ} \mathrm{C}$ for $4 \mathrm{~h}$. After completion of the reaction, the mixture was filtered and concentrated under reduced pressure to give a brown liquid. The residue was purified by flash chromatography on a silica gel (300-400 mesh) using ethyl acetate/petroleum ether as eluant to afford $2(86.1 \mathrm{~g}$, 90.1\%) as a brown liquid. ${ }^{1} \mathrm{H}$ NMR (600 MHz, DMSO-d $\left.\mathrm{d}_{6}\right): \delta 10.14$ (s, 1H, NH), 7.11-7.14 (m, 2H, Ph-H), 6.91-6.93 (m, 2H, Ph-H), 
$4.62(\mathrm{~s}, 1 \mathrm{H}, \mathrm{C}=\mathrm{CH}), 4.04\left(\mathrm{q}, J=7.0 \mathrm{~Hz}, 2 \mathrm{H}, \mathrm{OCH}_{2} \mathrm{CH}_{3}\right), 3.75(\mathrm{~s}$, $\left.3 \mathrm{H}, \mathrm{OCH}_{3}\right), 1.89\left(\mathrm{~s}, 3 \mathrm{H}, \mathrm{CH}_{3}\right), 1.19\left(\mathrm{t}, J=7.1 \mathrm{~Hz}, 3 \mathrm{H}, \mathrm{OCH}_{2} \mathrm{CH}_{3}\right)$. ${ }^{13} \mathrm{C}$ NMR (150 MHz, DMSO-d $\left.{ }_{6}\right): \delta 169.9(\mathrm{C}=\mathrm{O}), 160.3\left(\mathrm{NHCH}_{3}-\right.$ $\mathrm{C}=\mathrm{CH}), 157.4\left(\mathrm{C}-\mathrm{OCH}_{3}\right), 132.0$ (Ph-C), 126.7 (s, 2C, Ph-C), 114.7 (s, 2C, Ph-C), $84.8(\mathrm{C}=\mathrm{CH}), 58.5\left(\mathrm{OCH}_{2} \mathrm{CH}_{3}\right), 55.7\left(\mathrm{OCH}_{3}\right), 20.2$ $\left(\mathrm{OCH}_{2} \mathrm{CH}_{3}\right), 15.0\left(\mathrm{CH}_{3}\right)$. ESI-HRMS (+): $\mathrm{m} / z[\mathrm{M}+\mathrm{H}]^{+}$calculated for $\mathrm{C}_{13} \mathrm{H}_{18} \mathrm{NO}_{3}{ }^{+}, 236.1128$, found, 236.1281.

4.1.2 6-Methoxy-2-methylquinolin-4(1H)-one (3). A solution of ethyl 3-[(4-methoxyphenyl) imino] butanoate (2) (85.1 mmol, $20.0 \mathrm{~g}$ ) in diphenyl ether was heated to $250{ }^{\circ} \mathrm{C}$ for $30 \mathrm{~min}$. At the end of the period, the reaction mixture was cooled to $25{ }^{\circ} \mathrm{C}$ and diluted with ethyl acetate. Then crystalline solid separated out from the mixture, washed with ethyl acetate $(30.0 \mathrm{~mL})$ and dried in vacuum to give $3(8.3 \mathrm{~g}, 51.5 \%)$ as a white solid. ${ }^{1} \mathrm{H}$ NMR (600 MHz, DMSO-d $\left.\mathrm{d}_{6}\right): \delta 7.80\left(\mathrm{~d}, J=9.0 \mathrm{~Hz}, 1 \mathrm{H}, \mathrm{H}^{-}\right.$ 8), 7.50 (d, $J=2.8 \mathrm{~Hz}, 1 \mathrm{H}, \mathrm{H}-5), 7.45(\mathrm{dd}, J=2.8,9.1 \mathrm{~Hz}, 1 \mathrm{H}, \mathrm{H}-$ 7), 6.49 (s, 1H, H-3), 3.88 (s, 3H, $\left.\mathrm{OCH}_{3}\right), 2.54\left(\mathrm{~s}, 3 \mathrm{H}, \mathrm{CH}_{3}\right) \cdot{ }^{13} \mathrm{C}$ NMR (150 MHz, DMSO-d $\left.{ }_{6}\right): \delta 174.6(\mathrm{C}=\mathrm{O}), 156.2(\mathrm{C}-6), 150.5(\mathrm{C}-$ 2), 135.2 (C-9), 124.7 (C-10), 123.1 (C-7), 120.4 (C-8), 107.4 (C-3), 104.1 (C-5), $55.9\left(\mathrm{OCH}_{3}\right), 19.9\left(\mathrm{CH}_{3}\right)$. ESI-HRMS (+): $m / z[\mathrm{M}+\mathrm{H}]^{+}$ calculated for $\mathrm{C}_{11} \mathrm{H}_{12} \mathrm{NO}_{2}{ }^{+}, 190.0863$, found, 190.0862 .

4.1.3 4-Chloro-6-methoxy-2-methylquinoline (4). The mixture of 6-methoxy-2-methylquinolin-4-ol (3) (52.9 mmol, $10.0 \mathrm{~g}$ ) and $\mathrm{POCl}_{3}(60.0 \mathrm{~mL})$ was heated to $110{ }^{\circ} \mathrm{C}$ for $2 \mathrm{~h}$. After completion of the reaction, the excess of $\mathrm{POCl}_{3}$ was removed under reduced pressure. The residue was quenched into ice-water and stirred at $0{ }^{\circ} \mathrm{C}$ for $15 \mathrm{~min}$, then the $\mathrm{pH}$ was adjusted to 7 with saturated sodium hydroxide solution. The solid obtained was collected by filtration and dried in vacuum to give 4 as a white solid $(8.1 \mathrm{~g}$, $73.9 \%) .{ }^{1} \mathrm{H}$ NMR $\left(600 \mathrm{MHz}, \mathrm{CDCl}_{3}\right): \delta 7.83(\mathrm{~d}, J=9.2 \mathrm{~Hz}, 1 \mathrm{H}, \mathrm{H}-$ 8), 7.31 (d, $J=2.6 \mathrm{~Hz}, 1 \mathrm{H}, \mathrm{H}-5), 7.28-7.30$ (m, 1H, H-7), 7.27 (s, $1 \mathrm{H}, \mathrm{H}-3), 3.87\left(\mathrm{~s}, 3 \mathrm{H}, \mathrm{OCH}_{3}\right), 2.59\left(\mathrm{~s}, 3 \mathrm{H}, \mathrm{CH}_{3}\right) .{ }^{13} \mathrm{C} \mathrm{NMR}(150$ $\mathrm{MHz}, \mathrm{CDCl}_{3}$ ): $\delta 157.1$ (C-6), 155.0 (C-2), 143.7 (C-9), 140.0 (C-4), 129.5 (C-8), 124.6 (C-7), 122.0 (C-10), 121.1 (C-3), 100.7 (C-5), $54.6\left(\mathrm{OCH}_{3}\right), 23.7\left(\mathrm{CH}_{3}\right)$. ESI-HRMS $(+): \mathrm{m} / z[\mathrm{M}+\mathrm{H}]^{+}$calculated for $\mathrm{C}_{11} \mathrm{H}_{11} \mathrm{ClNO}^{+}$, 208.0524, found, 208.0524.

4.1.4 4-Chloro-2-methylquinolin-6-ol (5). To a cooled $\left(0{ }^{\circ} \mathrm{C}\right)$ solution of 4-chloro-6-methoxy-2-methylquinoline (4) $(24.3 \mathrm{mmol}$, $5.0 \mathrm{~g})$ in $\mathrm{CH}_{2} \mathrm{Cl}_{2}(50.0 \mathrm{~mL})$ was added dropwise $\mathrm{BBr}_{3}(26.6 \mathrm{~mL}$, $26.6 \mathrm{mmol}, 1 \mathrm{M}$ in $\mathrm{CH}_{2} \mathrm{Cl}_{2}$ ) under argon atmosphere. The reaction mixture was then allowed to warm to room temperature and stirred for $4 \mathrm{~h}$. The solvent was then condensed and the residue was slowly quenched with saturated aqueous $\mathrm{NaHCO}_{3}$ solution. The precipitate was filtered and washed with water to give $\mathbf{5}$ as an offwhite solid ( $3.4 \mathrm{~g}, 72.5 \%) .{ }^{1} \mathrm{H}$ NMR (600 MHz, DMSO-d $\left.\mathrm{d}_{6}\right): \delta 10.28$ (s, $1 \mathrm{H}, \mathrm{OH}$ ), 7.85 (d, $J=9.7 \mathrm{~Hz}, 1 \mathrm{H}, \mathrm{H}-8), 7.56$ (s, 1H, H-5), 7.34-7.37 $(\mathrm{m}, 2 \mathrm{H}, \mathrm{H}-3$ and $\mathrm{H}-7), 2.59\left(\mathrm{~s}, 3 \mathrm{H}, \mathrm{CH}_{3}\right) .{ }^{13} \mathrm{C} \mathrm{NMR}(150 \mathrm{MHz}$, DMSO-d 6 ): $\delta 156.6$ (C-6), 155.7 (C-2), 143.6 (C-9), 139.4 (C-4), 130.9 (C-8), 125.6 (C-7), 123.3 (C-10), 122.4 (C-3), 104.7 (C-5), $24.6\left(\mathrm{CH}_{3}\right)$. ESI-HRMS (+): $m / z[\mathrm{M}+\mathrm{H}]^{+}$calculated for $\mathrm{C}_{10} \mathrm{H}_{19} \mathrm{ClNO}^{+}, 194.0367$, found, 194.0368.

4.1.5 4-Chloro-6-ethoxy-2-methylquinoline (6a). A mixture of 4-chloro-2-methylquinolin-6-ol 5 (5.7 mmol, $1.1 \mathrm{~g})$, bromoethane $(10.3 \mathrm{mmol}, 1.6 \mathrm{~g})$ and potassium carbonate $(17.1 \mathrm{mmol}$, $2.4 \mathrm{~g})$ in DMF $(25.0 \mathrm{~mL})$ was stirred at $40{ }^{\circ} \mathrm{C}$ for $4 \mathrm{~h}$. The reaction mixture was filtered and the filtrate was concentrated in vacuo. The residue was purified by column chromatography with petroleum ether/ethyl acetate $(4: 1)$ to afford $\mathbf{6 a}$ as a white solid (1.2 g, 93.6\%). ${ }^{1} \mathrm{H}$ NMR (600 MHz, $\left.\mathrm{CDCl}_{3}\right): \delta 8.02(\mathrm{~d}, J=9.5 \mathrm{~Hz}$, 1H, H-8), 7.39-7.42 (m, 2H, H-5 and H-7), 7.38 (s, 1H, H-3), 4.19 $\left(\mathrm{q}, J=7.0 \mathrm{~Hz}, 2 \mathrm{H}, \mathrm{OCH}_{2} \mathrm{CH}_{3}\right), 2.72\left(\mathrm{~s}, 3 \mathrm{H}, \mathrm{CH}_{3}\right), 1.51(\mathrm{t}, J=$ $\left.7.0 \mathrm{~Hz}, 3 \mathrm{H}, \mathrm{OCH}_{2} \mathrm{CH}_{3}\right) .{ }^{13} \mathrm{C}$ NMR $\left(150 \mathrm{MHz}, \mathrm{CDCl}_{3}\right): \delta 157.6(\mathrm{C}-$ 6), 155.7 (C-2), 144.0 (C-9), 141.4 (C-4), 130.1 (C-8), 125.7 (C-7), 123.5 (C-10), 122.1 (C-3), 102.4 (C-5), $64.0\left(\mathrm{OCH}_{2} \mathrm{CH}_{3}\right), 24.5$ $\left(\mathrm{CH}_{3}\right), 14.7\left(\mathrm{OCH}_{2} \mathrm{CH}_{3}\right)$. ESI-HRMS (+): $\mathrm{m} / \mathrm{z}[\mathrm{M}+\mathrm{H}]^{+}$calculated for $\mathrm{C}_{12} \mathrm{H}_{13} \mathrm{ClNO}^{+}, 222.0680$, found, 222.0681.

4.1.6 4-Chloro-6-isopropoxy-2-methylquinoline (6b). A mixture of 4-chloro-2-methylquinolin-6-ol 5 (20.7 mmol, $4.0 \mathrm{~g}$ ), 2-bromopropane (41.4 mmol, $5.1 \mathrm{~g}$ ) and potassium carbonate $(62.1 \mathrm{mmol}, 8.6 \mathrm{~g})$ in DMF $(120.0 \mathrm{~mL})$ was stirred at $40{ }^{\circ} \mathrm{C}$ for $4 \mathrm{~h}$. The reaction mixture was filtered and the filtrate was concentrated in vacuo. The residue was purified by column chromatography using petroleum ether/ethyl acetate $(4: 1)$ to afford $\mathbf{6 b}$ as a white solid $(2.9 \mathrm{~g}, 59.6 \%) .{ }^{1} \mathrm{H}$ NMR $\left(600 \mathrm{MHz}, \mathrm{CDCl}_{3}\right): \delta 7.91$ (d, $J=9.2 \mathrm{~Hz}, 1 \mathrm{H}, \mathrm{H}-8), 7.43$ (d, $J=2.8 \mathrm{~Hz}, 1 \mathrm{H}, \mathrm{H}-5), 7.32-7.36$ (m, 2H, H-3 and $\mathrm{H}-7)$, 4.71-4.78 (m, 1H, OCH $\left.\left(\mathrm{CH}_{3}\right)_{2}\right), 2.67$ (s, $\left.3 \mathrm{H}, \mathrm{CH}_{3}\right), 1.43\left(\mathrm{~s}, 3 \mathrm{H}, \mathrm{OCH}\left(\mathrm{CH}_{3}\right)_{2}\right), 1.42\left(\mathrm{~s}, 3 \mathrm{H}, \mathrm{OCH}\left(\mathrm{CH}_{3}\right)_{2}\right) \cdot{ }^{13} \mathrm{C}$ NMR (150 MHz, $\mathrm{CDCl}_{3}$ ): $\delta 156.4$ (C-6), 155.7 (C-2), 143.9 (C-9), 141.3 (C-4), 130.2 (C-8), 125.7 (C-7), 124.1 (C-10), 122.1 (C-3), $104.0(\mathrm{C}-5), 70.4\left(\mathrm{OCH}\left(\mathrm{CH}_{3}\right)_{2}\right), 24.5\left(\mathrm{CH}_{3}\right), 21.9(\mathrm{~s}, 2 \mathrm{C}$, $\left.\mathrm{OCH}\left(\mathrm{CH}_{3}\right)_{2}\right)$. ESI-HRMS (+): $m / z[\mathrm{M}+\mathrm{H}]^{+}$calculated for $\mathrm{C}_{13} \mathrm{H}_{15} \mathrm{ClNO}^{+}$, 236.0837, found, 236.0837.

4.1.7 General procedure for the synthesis of 4-substitutedaminoquinoline compounds 7a-7w. A mixture of 4-chloroquinoline derivatives (6a-6b, $0.5 \mathrm{mmol})$, appropriate substituted anilines ( $0.6 \mathrm{mmol}, 1.2$ eq.) and 3 drops conc. $\mathrm{HC}$ in $n$-butanol $(15.0 \mathrm{~mL})$ was stirred at reflux for $8 \mathrm{~h}$. The reaction mixture was cooled to room temperature and the yellow solid formed was filtered, washed with diethyl ether and recrystallized from ethanol to afford the desired product.

4.1.7.1 N-(3,4-Dichlorophenyl)-6-methoxy-2-methylquinolin-4amine (7a). White solid; yield: $35.8 \%$; HPLC purity: $98.9 \%\left(t_{\mathrm{R}}=\right.$ $21.92 \mathrm{~min}$ ); mp: $266-267{ }^{\circ} \mathrm{C} .{ }^{1} \mathrm{H}$ NMR (600 MHz, DMSO-d 6 ): $\delta 8.08(\mathrm{~s}, 1 \mathrm{H}, \mathrm{H}-5), 7.96$ (d, $J=9.2 \mathrm{~Hz}, 1 \mathrm{H}, \mathrm{H}-8), 7.77$ (d, $J=$ $4.2 \mathrm{~Hz}, 1 \mathrm{H}, \mathrm{Ph}-\mathrm{H}), 7.76$ (d, $J=1.7 \mathrm{~Hz}, 1 \mathrm{H}, \mathrm{Ph}-\mathrm{H}), 7.58$ (dd, $J=$ 2.6, 9.2 Hz, 1H, H-7), 7.50 (dd, $J=2.4,8.6 \mathrm{~Hz}, 1 \mathrm{H}, \mathrm{Ph}-\mathrm{H}), 6.89$ (s, $1 \mathrm{H}, \mathrm{H}-3), 3.97\left(\mathrm{~s}, 3 \mathrm{H}, \mathrm{OCH}_{3}\right), 2.59\left(\mathrm{~s}, 3 \mathrm{H}, \mathrm{CH}_{3}\right) ;{ }^{13} \mathrm{C}$ NMR (150 MHz, DMSO-d 6 ): $\delta 157.9$ (C-2), 153.9 (C-6), 151.9 (C-4), 151.8 (C9), 139.2 (C-1'), 132.4 (Ph-C), 132.0 (C-8), 128.3 (Ph-C), 126.6 (PhC), 125.0 (C-7), 124.7 (Ph-C), 123.7 (Ph-C), 118.5 (C-10), 103.0 (C3), $101.9(\mathrm{C}-5), 56.8\left(\mathrm{OCH}_{3}\right), 21.1\left(\mathrm{CH}_{3}\right)$. ESI-HRMS (+): $\mathrm{m} / z[\mathrm{M}+$ $\mathrm{H}]^{+}$calculated for $\mathrm{C}_{17} \mathrm{H}_{15} \mathrm{Cl}_{2} \mathrm{~N}_{2} \mathrm{O}^{+}, 333.0556$, found, 333.0552 .

Other target compounds (7b-7B) were synthesized following the general procedure as described above with the yield of 25.0$86.0 \%$. Their structures were assigned by the spectroscopic data including ${ }^{1} \mathrm{H}$ NMR, ${ }^{13} \mathrm{C}$ NMR, and ESI-HRMS (see 'ESI $\dagger$ ').

4.1.8 4-((3,4-Dichlorophenyl)amino)-2-methylquinolin-6-ol (8). To a cooled $\left(0^{\circ} \mathrm{C}\right)$ solution of $7 \mathbf{a}(10.0 \mathrm{mmol}, 3.3 \mathrm{~g})$ in $\mathrm{CH}_{2} \mathrm{Cl}_{2}$ $(50.0 \mathrm{~mL})$ was added dropwise $\mathrm{BBr}_{3}(11.1 \mathrm{~mL}, 11.1 \mathrm{mmol}, 1 \mathrm{M}$ in $\mathrm{CH}_{2} \mathrm{Cl}_{2}$ ) under argon atmosphere. The reaction mixture was then allowed to warm to room temperature and stirred for $6 \mathrm{~h}$. The solvent was then condensed and the residue was slowly quenched with saturated aqueous $\mathrm{NaHCO}_{3}$ solution. The precipitate was filtered and washed with water to give $\mathbf{8}$ as an 
off-white solid (2.2 g, 68.0\%). ${ }^{1} \mathrm{H}$ NMR (600 MHz, DMSO-d 6 ): $\delta 8.76$ (br. s., $1 \mathrm{H}, \mathrm{OH}), 7.69$ (d, $J=9.0 \mathrm{~Hz}, 1 \mathrm{H}, \mathrm{H}-8), 7.55$ (d, $J=$ $8.6 \mathrm{~Hz}, 1 \mathrm{H}, \mathrm{Ph}-\mathrm{H}), 7.47$ (s, 1H, Ph-H), 7.40 (s, 1H, H-5), 7.28 (d, J $=8.4 \mathrm{~Hz}, 1 \mathrm{H}, \mathrm{Ph}-\mathrm{H}), 7.25(\mathrm{~d}, J=9.0 \mathrm{~Hz}, 1 \mathrm{H}, \mathrm{H}-7), 6.96(\mathrm{~s}, 1 \mathrm{H}, \mathrm{H}-$ 3), $2.45\left(\mathrm{~s}, 3 \mathrm{H}, \mathrm{CH}_{3}\right) .{ }^{13} \mathrm{C}$ NMR (150 MHz, DMSO-d 6 ): $\delta 156.4(\mathrm{C}-$ 2), 153.3 (C-6), 151.9 (C-4), 145.6 (C-9), 139.2 (C-1'), 132.4 (Ph-C), 132.0 (C-8), 128.3 (Ph-C), 126.5 (Ph-C), 124.9 (C-7), 124.7 (Ph-C), 123.3 (Ph-C), 118.9 (C-10), 105.6 (C-3), 101.7 (C-5), $21.0\left(\mathrm{CH}_{3}\right)$. ESI-HRMS (+): $m / z[\mathrm{M}+\mathrm{H}]^{+}$calculated for $\mathrm{C}_{16} \mathrm{H}_{13} \mathrm{Cl}_{2} \mathrm{~N}_{2} \mathrm{O}^{+}$, 319.0399, found, 319.0398.

4.1.9 General procedure for the synthesis of 9a-9e (general procedure for the alkylation of phenols). A mixture of 4-(3,4dichlorobenzyl)-2-methylquinolin-6-ol (8) (1.0 mmol), appropriate alkyl halides $(1.1 \mathrm{mmol})$, and potassium carbonate (331 mg, $2.4 \mathrm{mmol})$ in DMF $(6.0 \mathrm{~mL})$ was stirred at $40{ }^{\circ} \mathrm{C}$ for $4 \mathrm{~h}$. The reaction mixture was filtered and the filtrate was concentrated in vacuo. The residue was purified by column chromatography using appropriate mixtures of ethyl acetate and petroleum to yield the titled compound.

4.1.9.1 N-(3,4-Dichlorophenyl)-2-methyl-6-propoxyquinolin-4amine (9a). White solid; yield: 30.0\%; HPLC purity: $96.1 \%\left(t_{\mathrm{R}}=\right.$ $23.96 \mathrm{~min}$ ); mp: $266-267{ }^{\circ} \mathrm{C} .{ }^{1} \mathrm{H}$ NMR (600 MHz, DMSO-d 6 ): $\delta 7.77(\mathrm{~d}, J=9.2 \mathrm{~Hz}, 1 \mathrm{H}, \mathrm{H}-8), 7.69(\mathrm{~d}, J=2.0 \mathrm{~Hz}, 1 \mathrm{H}, \mathrm{H}-5), 7.63$ (d, $J=8.6 \mathrm{~Hz}, 1 \mathrm{H}, \mathrm{Ph}-\mathrm{H}), 7.58$ (d, $J=2.4 \mathrm{~Hz}, 1 \mathrm{H}, \mathrm{Ph}-\mathrm{H}), 7.36-$ $7.40(\mathrm{~m}, 2 \mathrm{H}), 6.94(\mathrm{~s}, 1 \mathrm{H}, \mathrm{H}-3), 4.08\left(\mathrm{t}, J=6.5 \mathrm{~Hz}, 2 \mathrm{H}, \mathrm{OCH}_{2}\right)$, 2.49 (s, $3 \mathrm{H}, \mathrm{CH}_{3}$ ), 1.81 (sxt, $J=7.0 \mathrm{~Hz}, 2 \mathrm{H}, \mathrm{OCH}_{2} \mathrm{CH}_{2} \mathrm{CH}_{3}$ ), 1.03 $\left(\mathrm{t}, J=7.3 \mathrm{~Hz}, 3 \mathrm{H}, \mathrm{OCH}_{2} \mathrm{CH}_{2} \mathrm{CH}_{3}\right) ;{ }^{13} \mathrm{C}$ NMR (150 MHz, DMSO$\mathrm{d}_{6}$ ): $\delta 156.2$ (C-2), 155.9 (C-6), 147.1 (C-4), 143.0 (C-9), 141.7 (C1'), 132.1 (Ph-C), 131.6 (C-8), 129.1 (Ph-C), 125.0 (C-7), 123.5 (PhC), 122.3 (Ph-C), 121.9 (Ph-C), 119.6 (C-10), 103.7 (C-3), 102.5 (C5), $70.0\left(\mathrm{OCH}_{2}\right), 24.4\left(\mathrm{OCH}_{2} \mathrm{CH}_{2} \mathrm{CH}_{3}\right), 22.5(\mathrm{C}-11), 11.0\left(\mathrm{OCH}_{2}-\right.$ $\left.\mathrm{CH}_{2} \mathrm{CH}_{3}\right)$. ESI-HRMS (+): $m / z \quad[\mathrm{M}+\mathrm{H}]^{+}$calculated for $\mathrm{C}_{19} \mathrm{H}_{19} \mathrm{Cl}_{2} \mathrm{~N}_{2} \mathrm{O}^{+}$, 361.0869, found, 361.0865.

Other target compounds (9b-9e) were synthesized following the general procedure as described above with the yield of 30.0$55.0 \%$. Their structures were assigned by the spectroscopic data including ${ }^{1} \mathrm{H}$ NMR, ${ }^{13} \mathrm{C}$ NMR, and ESI-HRMS (see 'ESI $\dagger$ ').

4.1.10 General procedure for the synthesis of 10a-10d (hydrolysis). A mixture of 4-(3,4-dichlorobenzyl)-2-methylquinolin6-ol (8) (1.0 mmol), various lengths of ethyl or methyl bromoalkanoate $(1.1 \mathrm{mmol})$, and potassium carbonate $(331 \mathrm{mg}, 2.4$ $\mathrm{mmol})$ in acetone $(10.0 \mathrm{~mL})$ was stirred at $40{ }^{\circ} \mathrm{C}$ for $4 \mathrm{~h}$. The reaction mixture was filtered and the filtrate was concentrated in vacuo. The residue was purified by column chromatography using appropriate mixtures of ethyl acetate and petroleum to yield the titled compound.

4.1.10.1 Methyl 6-((4-((3,4-dichlorophenyl)amino)-2-methylquinolin6-yl)oxy)hexanoate (10c). White solid; yield: 64.2\%; HPLC purity: 93.3\% $\left(t_{\mathrm{R}}=24.35 \mathrm{~min}\right)$; $\mathrm{mp}: 129-131{ }^{\circ} \mathrm{C} .{ }^{1} \mathrm{H}$ NMR $(600 \mathrm{MHz}$, $\left.\mathrm{CDCl}_{3}\right): \delta 7.90(\mathrm{~d}, J=9.2 \mathrm{~Hz}, 1 \mathrm{H}, \mathrm{H}-8), 7.44(\mathrm{~d}, J=8.6 \mathrm{~Hz}, 1 \mathrm{H}, \mathrm{Ar}-$ $\mathrm{H}), 7.38$ (d, $J=2.6 \mathrm{~Hz}, 1 \mathrm{H}, \mathrm{H}-5), 7.30-7.33$ (m, 1H, H-7), 7.137.17 (m, 2H, Ar-H), 6.92 (s, 1H, H-3), 3.96-4.04 (m, 2H, 12- $\mathrm{CH}_{2}$ ), $3.68\left(\mathrm{~s}, 3 \mathrm{H}, \mathrm{COO}-\mathrm{CH}_{3}\right), 2.58\left(\mathrm{~s}, 3 \mathrm{H}, 11-\mathrm{CH}_{3}\right), 2.34-2.41(\mathrm{~m}, 2 \mathrm{H})$, 1.81-1.85 (m, 2H), 1.69-1.73 (m, 2H), 1.47-1.54 (m, 2H); ${ }^{13} \mathrm{C}$ NMR (150 MHz, $\left.\mathrm{CDCl}_{3}\right): \delta 173.3(\mathrm{C}=\mathrm{O}), 155.7(\mathrm{C}-2), 155.3$ (C-6), 145.0 (C-4), 143.4 (C-9), 139.7 (C-1'), 132.2 (Ph-C), 130.0 (C-8), 129.2 (Ph-C), 125.5 (C-7), 121.9 (Ph-C), 120.9 (Ph-C), 119.7 (C-
10), 118.5 (Ph-C), 103.5 (C-3), 99.4 (C-5), 67.0 (C-12), 50.6 (COO- $\mathrm{CH}_{3}$ ), 32.9, 27.7, 24.5, 23.5 (C-11). ESI-HRMS (+): $m / z[\mathrm{M}+$ $\mathrm{H}]^{+}$calculated for $\mathrm{C}_{23} \mathrm{H}_{25} \mathrm{Cl}_{2} \mathrm{~N}_{2} \mathrm{O}_{3}{ }^{+}, 447.1237$, found, 447.1236.

4.1.10.2 Ethyl 7-((4-((3,4-dichlorophenyl)amino)-2-methylquinolin6-yl)oxy)heptanoate (10d). White solid; yield: 59.1\%; HPLC purity: 96.4\% $\left(t_{\mathrm{R}}=25.76 \mathrm{~min}\right)$; mp: $129-132{ }^{\circ} \mathrm{C} .{ }^{1} \mathrm{H} \mathrm{NMR}(600 \mathrm{MHz}$, $\left.\mathrm{CDCl}_{3}\right): \delta 7.90(\mathrm{~d}, J=9.2 \mathrm{~Hz}, 1 \mathrm{H}, \mathrm{H}-8), 7.43(\mathrm{~d}, J=8.6 \mathrm{~Hz}, 1 \mathrm{H}, \mathrm{Ph}-$ $\mathrm{H}), 7.37(\mathrm{~d}, J=2.4 \mathrm{~Hz}, 1 \mathrm{H}, \mathrm{H}-5), 7.31(\mathrm{dd}, J=2.6,9.2 \mathrm{~Hz}, 1 \mathrm{H}, \mathrm{H}-$ 7), 7.17-7.20 (m, 1H, Ph-H), 7.14 (dd, $J=2.5,8.5 \mathrm{~Hz}, 1 \mathrm{H}, \mathrm{Ph}-\mathrm{H})$, $6.91(\mathrm{~s}, 1 \mathrm{H}, \mathrm{H}-3), 4.12\left(\mathrm{q}, J=7.0 \mathrm{~Hz}, 2 \mathrm{H}, \mathrm{COO}-\mathrm{CH}_{2} \mathrm{CH}_{3}\right), 3.98(\mathrm{t}, J$ $\left.=6.4 \mathrm{~Hz}, 2 \mathrm{H}, 12-\mathrm{CH}_{2}\right), 2.58\left(\mathrm{~s}, 3 \mathrm{H}, 11-\mathrm{CH}_{3}\right), 2.28-2.35(\mathrm{~m}, 2 \mathrm{H})$, $1.79-1.82(\mathrm{~m}, 2 \mathrm{H}), 1.66$ (quin, $J=7.5 \mathrm{~Hz}, 2 \mathrm{H}), 1.43-1.51(\mathrm{~m}, 2 \mathrm{H})$, 1.35-1.42 (m, 2H), $1.25\left(\mathrm{t}, J=7.2 \mathrm{~Hz}, 1 \mathrm{H}, \mathrm{COO}-\mathrm{CH}_{2} \mathrm{CH}_{3}\right) ;{ }^{13} \mathrm{C}$ NMR (150 MHz, $\left.\mathrm{CDCl}_{3}\right): \delta 174.0(\mathrm{C}=\mathrm{O}), 156.7(\mathrm{C}-2), 156.5(\mathrm{C}-6)$, 146.0 (C-4), 144.4 (C-9), 140.7 (C-1'), 133.3 (Ph-C), 131.1 (C-8), 130.3 (Ph-C), 126.6 (C-7), 123.0 (Ph-C), 121.8 (Ph-C), 120.8 (PhC), 119.5 (C-10), 104.5 (C-3), 100.2 (C-5), 68.2 (C-12), 60.4 $\left(\mathrm{COO}-\mathrm{CH}_{2} \mathrm{CH}_{3}\right.$ ), 34.2, 28.8, 28.7, 25.6, 25.1, 24.8 (C-11), 14.2 (COO- $\mathrm{CH}_{2} \mathrm{CH}_{3}$ ). ESI-HRMS (+): $\mathrm{m} / z[\mathrm{M}+\mathrm{H}]^{+}$calculated for $\mathrm{C}_{25} \mathrm{H}_{29} \mathrm{Cl}_{2} \mathrm{~N}_{2} \mathrm{O}_{3}{ }^{+}$, 475.1550, found, 475.1549.

Other target compounds (10a-10b) were synthesized following the general procedure as described above with the yield of $34.0-64.0 \%$. Their structures were assigned by the spectroscopic data including ${ }^{1} \mathrm{H}$ NMR, ${ }^{13} \mathrm{C}$ NMR, and ESI-HRMS (see 'ESI†').

4.1.11 General procedure for the synthesis of 11a-11d. To a solution of 10a-10d $(0.5 \mathrm{mmol})$ in $\mathrm{EtOH}(5.0 \mathrm{~mL})$ was added a $20 \%$ aqueous $\mathrm{NaOH}$ solution and the reaction mixture was stirred at room temperature for $1 \mathrm{~h}$. The mixture was neutralized by the addition of a $10.0 \%$ aqueous $\mathrm{HCl}$ solution. The resulting precipitate was filtered, washed with diethyl ether and recrystallized from ethanol to afford the corresponding carboxylic acid compound.

4.1.11.1 4-((4-((3,4-dichlorophenyl)amino)-2-methylquinolin6-yl)oxy) butanoic acid (11a). White solid; yield: 70.0\%; HPLC purity: $97.0 \%\left(t_{\mathrm{R}}=21.99 \mathrm{~min}\right)$; mp: $266-267{ }^{\circ} \mathrm{C} .{ }^{1} \mathrm{H}$ NMR (600 MHz, DMSO-d $\left.{ }_{6}\right): \delta 7.79(\mathrm{~d}, J=9.2 \mathrm{~Hz}, 1 \mathrm{H}, \mathrm{H}-8), 7.72(\mathrm{~d}, J=$ $2.4 \mathrm{~Hz}, 1 \mathrm{H}, \mathrm{H}-5), 7.65$ (d, $J=8.8 \mathrm{~Hz}, 1 \mathrm{H}, \mathrm{Ph}-\mathrm{H}), 7.59$ (d, $J=$ $2.6 \mathrm{~Hz}, 1 \mathrm{H}, \mathrm{Ph}-\mathrm{H}), 7.39\left(\mathrm{td}, J=2.2,8.8 \mathrm{~Hz}, 2 \mathrm{H}, \mathrm{H}-7\right.$ and $\mathrm{H}-6^{\prime}$ ), $6.93(\mathrm{~s}, 1 \mathrm{H}, \mathrm{H}-3), 4.14\left(\mathrm{t}, J=6.4 \mathrm{~Hz}, 2 \mathrm{H}, 12-\mathrm{CH}_{2}\right), 2.49(\mathrm{~s}, 3 \mathrm{H}$, $\mathrm{CH}_{3}$ ), $2.45\left(\mathrm{t}, J=7.2 \mathrm{~Hz}, 2 \mathrm{H}, 14-\mathrm{CH}_{2}\right.$ ), 2.03 (quin, $J=6.8 \mathrm{~Hz}, 2 \mathrm{H}$, 13- $\left.\mathrm{CH}_{2}\right) ;{ }^{13} \mathrm{C}$ NMR (150 MHz, DMSO-d $\left.{ }_{6}\right): \delta 174.6(\mathrm{C}=\mathrm{O}), 156.2$ (C-2), 155.8 (C-6), 147.7 (C-4), 142.1 (C-9), 141.3 (C-1'), 132.1 (PhC), 131.7 (C-8), 128.4 (Ph-C), 125.5 (C-7), 124.0 (Ph-C), 122.7 (PhC), 122.4 (Ph-C), 119.3 (C-10), 103.3 (C-3), 102.5 (C-5), 67.7 $\left(\mathrm{OCH}_{2}\right), 30.6\left(\mathrm{CH}_{2}-\mathrm{COOH}\right), 24.7\left(\mathrm{OCH}_{2} \mathrm{CH}_{2}\right), 24.0$ (C-11). ESIHRMS (-): $m / z[\mathrm{M}-\mathrm{H}]^{-}$calculated for $\mathrm{C}_{20} \mathrm{H}_{17} \mathrm{Cl}_{2} \mathrm{~N}_{2} \mathrm{O}_{3}{ }^{-}$, 403.0622, found, 403.0618 .

Other target compounds (11b-11d) were synthesized following the general procedure as described above with the yield of 70.091.0\%. Their structures were assigned by the spectroscopic data including ${ }^{1} \mathrm{H}$ NMR, ${ }^{13} \mathrm{C}$ NMR, and ESI-HRMS (see 'ESI $\dagger$ ').

4.1.12 General procedure for the synthesis of $12 \mathrm{a}-12 \mathrm{~d}$ from their corresponding esters. The appropriate esters 10a-10d $(0.2$ $\mathrm{mmol}), \mathrm{NaOH}(2.3 \mathrm{mmol})$ and hydroxylamine solution (6.9 $\mathrm{mmol})$ was added to $\mathrm{DCM} / \mathrm{CH}_{3} \mathrm{OH}=1: 2(2.0 \mathrm{~mL} / 4.0 \mathrm{~mL})$ at $0{ }^{\circ} \mathrm{C}$. The reaction mixture was warmed to room temperature 
and stirred at $25{ }^{\circ} \mathrm{C}$ for $24 \mathrm{~h}$. After completion of the reaction (monitored by TLC), the mixture was neutralized with acetic acid. The formed precipitate was collected by filtration, washed with water and recrystallized from ethanol to give the crude product. The crude was purified by column chromatography using appropriate mixtures of dichloromethane and methanol to yield the titled compound.

4.1.12.1 6-((4-((3,4-dichlorophenyl)amino)-2-methylquinolin-6yl)oxy)-N-hydroxy-hexanamide (12c). White solid; yield: $50.1 \%$; HPLC purity: $97.9 \%\left(t_{\mathrm{R}}=22.09 \mathrm{~min}\right)$; mp: $266-267{ }^{\circ} \mathrm{C} .{ }^{1} \mathrm{H}$ NMR (600 MHz, $\left.\mathrm{CD}_{3} \mathrm{OD}\right): \delta 7.70(\mathrm{~d}, J=9.2 \mathrm{~Hz}, 1 \mathrm{H}, \mathrm{H}-8), 7.65(\mathrm{~d}, J=$ $2.4 \mathrm{~Hz}, 1 \mathrm{H}, \mathrm{H}-5), 7.54$ (d, $J=8.6 \mathrm{~Hz}, 1 \mathrm{H}, \mathrm{Ph}-\mathrm{H}), 7.52$ (d, $J=$ $2.6 \mathrm{~Hz}, 1 \mathrm{H}, \mathrm{Ph}-\mathrm{H}$ ), 7.41 (dd, $J=2.5,9.3 \mathrm{~Hz}, 1 \mathrm{H}, \mathrm{H}-7), 7.30$ (dd, $J$ $=2.4,8.6 \mathrm{~Hz}, 1 \mathrm{H}, \mathrm{Ph}-\mathrm{H}), 6.75(\mathrm{~s}, 1 \mathrm{H}, \mathrm{H}-3), 4.07(\mathrm{t}, J=6.3 \mathrm{~Hz}, 2 \mathrm{H}$, $\left.12-\mathrm{CH}_{2}\right), 2.48\left(\mathrm{~s}, 3 \mathrm{H}, \mathrm{CH}_{3}\right), 2.05\left(\mathrm{t}, J=7.3 \mathrm{~Hz}, 2 \mathrm{H}, 16-\mathrm{CH}_{2}\right), 1.74-$ $1.85\left(\mathrm{~m}, 2 \mathrm{H}, 13-\mathrm{CH}_{2}\right.$ ), 1.62 (quin, $J=7.6 \mathrm{~Hz}, 2 \mathrm{H}, 15-\mathrm{CH}_{2}$ ), 1.43$1.51\left(\mathrm{~m}, 2 \mathrm{H}, 14-\mathrm{CH}_{2}\right) ;{ }^{13} \mathrm{C}$ NMR (150 MHz, $\left.\mathrm{CD}_{3} \mathrm{OD}\right): \delta 171.4(\mathrm{C}=$ O), 157.7 (C-2), 153.9 (C-6), 151.8 (C-4), 138.7 (C-9), 136.9 (C-1'), 133.0 (Ph-C), 131.3 (C-8), 129.1 (Ph-C), 125.8 (C-7), 124.4 (Ph-C), 123.8 (Ph-C), 123.4 (Ph-C), 118.3 (C-10), 101.7 (C-3), 101.2 (C-5), 68.3 (C-12), 32.3 (C-16), 28.4 (C-13), 25.2 (C-15), 25.0 (C-14), 20.1 (C-11). ESI-HRMS (-): $m / z[\mathrm{M}-\mathrm{H}]^{-}$calculated for $\mathrm{C}_{22} \mathrm{H}_{22} \mathrm{Cl}_{2^{-}}$ $\mathrm{N}_{3} \mathrm{O}_{3}{ }^{-}, 446.1044$, found, 446.1040.

4.1.12.2 7-((4-((3,4-Dichlorophenyl)amino)-2-methylquinolin-6yl)oxy)-N-hydroxy-heptanamide (12d). White solid; yield: 64.9\%; HPLC purity: $98.4 \%\left(t_{\mathrm{R}}=22.76 \mathrm{~min}\right)$; mp: $266-267{ }^{\circ} \mathrm{C} .{ }^{1} \mathrm{H}$ NMR (600 MHz, DMSO-d $\left.{ }_{6}\right): \delta 7.72(\mathrm{~d}, J=9.0 \mathrm{~Hz}, 1 \mathrm{H}, \mathrm{H}-8), 7.68(\mathrm{~d}, J=$ $2.6 \mathrm{~Hz}, 1 \mathrm{H}, \mathrm{H}-5), 7.59$ (d, $J=0.9 \mathrm{~Hz}, 1 \mathrm{H}, \mathrm{Ph}-\mathrm{H}), 7.58$ (d, $J=$ $4.8 \mathrm{~Hz}, 1 \mathrm{H}, \mathrm{Ph}-\mathrm{H}), 7.38$ (dd, $J=2.5,8.7 \mathrm{~Hz}, 1 \mathrm{H}, \mathrm{Ph}-\mathrm{H}), 7.30$ (dd, $=2.6,9.2 \mathrm{~Hz}, 1 \mathrm{H}, \mathrm{H}-7), 6.96(\mathrm{~s}, 1 \mathrm{H}, \mathrm{H}-3), 4.11(\mathrm{t}, J=6.4 \mathrm{~Hz}, 2 \mathrm{H}$, $\mathrm{H}-12), 2.46$ (s, 3H, $\mathrm{CH}_{3}$ ), 2.17 (t, $\left.J=7.2 \mathrm{~Hz}, 2 \mathrm{H}, \mathrm{H}-17\right), 1.74-1.82$ (m, 2H, H-13), 1.52 (quin, $J=7.4 \mathrm{~Hz}, 2 \mathrm{H}, \mathrm{H}-16$ ), 1.45 (quin, $J=$ $7.5 \mathrm{~Hz}, 2 \mathrm{H}, \mathrm{H}-14), 1.31-1.39$ (m, 2H, H-13); ${ }^{13} \mathrm{C} \mathrm{NMR}(150 \mathrm{MHz}$, DMSO-d 6 ): $\delta 169.6(\mathrm{C}=\mathrm{O}), 157.1(\mathrm{C}-2), 154.1(\mathrm{C}-6), 153.0(\mathrm{C}-4)$, 139.7 (C-9), 138.2 (C-1'), 134.3 (Ph-C), 131.8 (C-8), 130.3 (Ph-C), 125.6 (C-7), 125.1 (Ph-C), 124.4 (Ph-C), 122.7 (Ph-C), 118.6 (C10), 103.4 (C-3), 100.3 (C-5), 69.0 (C-12), 49.1 (C-17), 32.7 (C13), 28.8 (C-15), 25.8 (C-16), 25.5 (C-14), 20.6 (C-11). ESI-HRMS $(-): m / z[\mathrm{M}-\mathrm{H}]^{-}$calculated for $\mathrm{C}_{23} \mathrm{H}_{24} \mathrm{Cl}_{2} \mathrm{~N}_{3} \mathrm{O}_{3}{ }^{-}$, 426.1200, found, 426.1197.

Other target compounds (12a-12b) were synthesized following the general procedure as described above with the yield of $35.0-65.0 \%$. Their structures were assigned by the spectroscopic data including ${ }^{1} \mathrm{H}$ NMR, ${ }^{13} \mathrm{C}$ NMR, and ESI-HRMS (see 'ESI†').

\subsection{Biological assays}

4.2.1 Reagents, antibody and cell lines. SAHA, 3-(4,5dimethylthiazol-2-yl)-2,5-diphenyltetrazoliumbromide (MTT) and DMSO were purchased from MedChemExpress. The antiacetylated histone $\mathrm{H} 3$ and $\mathrm{H} 4$ antibodies were from Santa Cruz Biotechnology. The horseradish peroxidase (HRP) conjugated secondary antibodies were obtained from Thermo Fisher Scientific and the antibodies against $\alpha$-tubulin (T6074), polymerase (Parp) (9542) and Flag (F1804) were from sigma. The rabbit polyclonal anti-HEXIM1, -CDK9, and -LARP7 antibodies have been described previously. ${ }^{\mathbf{5 8 , 5 9}}$ All the cell lines used in this study were either purchased from American Type Culture Collection (ATCC, Manassas,VA) or described as previously. ${ }^{47}$

4.2.2 Cell culture. J-Lat A2 and 2D10 cells were cultured in 1640 medium (Life Technological) with $10 \%$ fetal bovine serum and kept in a $\mathrm{CO}_{2}$ incubator which consisted of a humidified atmosphere of $5 \% \mathrm{CO}_{2}$ at $37^{\circ} \mathrm{C}$. All the cancer cells (HeLa, A549, NH1, NH2 and HepG2) were grown in DMEM medium (Life Technological) with $10 \%$ fetal bovine serum in a humidified atmosphere containing $5 \% \mathrm{CO}_{2}$ at $37^{\circ} \mathrm{C}$.

4.2.3 Flow cytometry screening. The Flow cytometry screening assay was performed in Jurkat-based cells line (J-Lat A2) containing LTR-Tat-IRES-GFP-LTR ${ }^{\mathbf{4}}$ and 2D10 cells harboring the nearly complete HIV-1 genome except for the nef gene that is replaced by the GFP-coding sequence. ${ }^{45}$ After incubation with the indicated compounds or $0.1 \%$ dimeththyl sulfoxide (DMSO) as negative control, cells were harvested and washed twice with $1 \times$ phosphate buffered saline (PBS) and analyzed the expression of GFP by flow cytometer (Epics Altra, BECKMAN COULTER).

4.2.4 Luciferase assay. The luciferase assay was conducted in $\mathrm{NH} 1$ and $\mathrm{NH} 2$, a pair of HeLa-based isogenic cell lines, both of which contain an integrated HIV-1 LTR-luciferase reporter gene but only the latter stably expresses HIV-1 Tat. ${ }^{47,51}$ Cells in twelvewell plate were treated with different concentration of 12c, $12 d$ or DMSO for $24 \mathrm{~h}$, then the cell lysates were normalized and measured luciferase activity using luciferase kit from Promega.

4.2.5 Western blotting. Equal amounts of the lysates were electrophoresed on 8\% SDS-PAGE gel and transferred to PVDF membranes $(0.22 \mu \mathrm{M})$. The membranes were blocked with $5 \%$ nonfat milk in TBST (50 mM Tris-HCl, pH7.4, $150.0 \mathrm{mM} \mathrm{NaCl}$ and $0.1 \%$ Tween 20 ) buffer for $1 \mathrm{~h}$ at room temperature and incubated with various primary antibodies overnight at $4{ }^{\circ} \mathrm{C}$. After three TBST washes, the membranes were incubated with HRP-conjugated anti-mouse or anti-rabbit antibody for $2 \mathrm{~h}$ at room temperature. The final immunoreactive products were detected with an enhanced chemiluminescence (ECL) system.

4.2.6 Co-immunoprecipitation. The coimmunoprecipitation assay was performed as described with minor modifications. ${ }^{60}$ Briefly, to detect the dissociation of 7SK snRNP after compounds treatment, nuclear extracts (NEs) were made from F1C2 cells, a HeLa-based cell line stably expressing CDK9-Flag. ${ }^{59}$ One day later, the cells were treated with $5 \mu \mathrm{M} \mathrm{12c}$, 12d or DMSO as a control for $24 \mathrm{~h}$ and then subjected to the preparation of NEs. For anti-Flag IP, NEs were incubated with antiFlag agarose beads (sigma) for $4 \mathrm{~h}$ at a ratio of $10 \mu \mathrm{L}$ beads per 100 $\mu \mathrm{L}$ NEs. After extensive washing, the eluted proteins were analyzed by western blotting with the indicated antibodies.

4.2.7 Statistical analysis. The data were expressed as mean \pm SD. Each assay was repeated in triplicate in three independent experiments. Statistical significance of differences between groups was analysed by using Student's $t$-test or analysis of variance. $P<0.05$ was considered significant.

\subsection{Molecular modeling}

X-ray protein structure of human HDAC2 (PDB code: 4LXZ) was download from Protein Data Bank (PDB) and prepared 
with Protein Preparation Wizard panel as implemented in Maestro 10.5 (Schrödinger Release 2016-1: Maestro, Schrödinger, LLC, New York, NY, 2016.). Missing hydrogens and residues were added, bond orders were assigned, and water molecules beyond $5 \AA$ to inhibitor were removed. Both the native ligand SAHA and compound $12 \mathrm{c}$ were prepared with LigPrep panel with OPLS2005 force field, generating the protonation and tautomeric states at $7.0 \pm 2.0 \mathrm{pH}$ units. The glide grid center was setting according the geometrical center of original inhibitor (SAHA) and the grid size was $20 \times 20 \times$ $20 \AA^{3}$, in which the metal coordination was set for $\mathrm{ZN}^{2+}$ in the binding site. Prior to docking compound 12c, a re-docking run was performed to evaluate the docking performance of Glide extra precision (Glide XP) mode. Glide XP mode (Schrödinger Release 2016-1: Glide, Schrödinger, LLC, New York, NY, 2017.) was successful in reproducing the binding mode of native ligand SAHA with a RMSD value of $0.773 \AA$. Then based on this docking grid, all inhibitors including the co-crystal ligand SAHA were docked flexibly by Glide 7.0 in extra precision with default options.

\section{Conflicts of interest}

There are no conflicts to declare.

\section{Acknowledgements}

This work was supported by the National Natural Science Foundation of China (No. 81773600, 81672955 and 81302652), the Natural Science Foundation of Fujian Province of China (No. 2018J01132 and 2016J011172), and the Fundamental Research Funds for the Central Universities (No. 20720180051 and 20720160062) to Y. X. This research was also sponsored by the Scientific Research Foundation of Third Institute of Oceanography, SOA (Grant No. 2016042) and the Educational Department of Fujian Province (JA15017).

\section{References}

1 D. Finzi, J. Blankson, J. D. Siliciano, J. B. Margolick, K. Chadwick, T. Pierson, K. Smith, J. Lisziewicz, F. Lori, C. Flexner, T. C. Quinn, R. E. Chaisson, E. Rosenberg, B. Walker, S. Gange, J. Gallant and R. F. Siliciano, Nat Med, 1999, 5, 512-517.

2 J. D. Siliciano, J. Kajdas, D. Finzi, T. C. Quinn, K. Chadwick, J. B. Margolick, C. Kovacs, S. J. Gange and R. F. Siliciano, Nat Med, 2003, 9, 727-728.

3 A. R. Cillo and J. W. Mellors, Curr. Opin. Virol., 2016, 18, 1419.

4 A. S. S. W. G. o. H. I. V. C. International, S. G. Deeks, B. Autran, B. Berkhout, M. Benkirane, S. Cairns, N. Chomont, T. W. Chun, M. Churchill, M. Di Mascio, C. Katlama, A. Lafeuillade, A. Landay, M. Lederman, S. R. Lewin, F. Maldarelli, D. Margolis, M. Markowitz, J. Martinez-Picado, J. I. Mullins, J. Mellors, S. Moreno, U. O'Doherty, S. Palmer, M. C. Penicaud, M. Peterlin, G. Poli, J. P. Routy, C. Rouzioux, G. Silvestri, M. Stevenson,
A. Telenti, C. Van Lint, E. Verdin, A. Woolfrey, J. Zaia and F. Barre-Sinoussi, Nat. Rev. Immunol., 2012, 12, 607-614.

5 J. D. Siliciano and R. F. Siliciano, J. Clin. Invest., 2016, 126, 409-414.

6 K. M. Barton, B. D. Burch, N. Soriano-Sarabia and D. M. Margolis, Clin. Pharmacol. Ther., 2013, 93, 46-56.

7 C. Schwartz, S. Bouchat, C. Marban, V. Gautier, C. Van Lint, O. Rohr and V. Le Douce, Biochem. Pharmacol., 2017, 146, 1022.

8 S. G. Deeks, Nature, 2012, 487, 439-440.

9 G. Darcis, B. Van Driessche and C. Van Lint, Trends Immunol., 2017, 38, 217-228.

10 P. K. Datta, R. Kaminski, W. Hu, V. Pirrone, N. T. Sullivan, M. R. Nonnemacher, W. Dampier, B. Wigdahl and K. Khalili, Curr. HIV Res., 2016, 14, 431-441.

11 D. M. Margolis, J. V. Garcia, D. J. Hazuda and B. F. Haynes, Science, 2016, 353, aaf6517.

12 N. M. Archin and D. M. Margolis, Curr. Opin. Infect. Dis., 2014, 27, 29-35.

13 J. T. Kimata, A. P. Rice and J. Wang, Curr. Opin. Immunol., 2016, 42, 65-70.

14 S. Xing and R. F. Siliciano, Drug discovery today, 2013, 18, 541-551.

15 D. M. Margolis, Curr. Opin. HIV AIDS, 2011, 6, 25-29.

16 X. Contreras, M. Barboric, T. Lenasi and B. M. Peterlin, PLoS Pathog., 2007, 3, 1459-1469.

17 J. Kulkosky, D. M. Culnan, J. Roman, G. Dornadula, M. Schnell, M. R. Boyd and R. J. Pomerantz, Blood, 2001, 98, 3006-3015.

18 M. Stoszko, E. De Crignis, C. Rokx, M. M. Khalid, C. Lungu, R. J. Palstra, T. W. Kan, C. Boucher, A. Verbon, E. C. Dykhuizen and T. Mahmoudi, EBioMedicine, 2016, 3, 108-121.

19 N. M. Archin, A. Espeseth, D. Parker, M. Cheema, D. Hazuda and D. M. Margolis, AIDS Res. Hum. Retroviruses, 2009, 25, 207-212.

20 (a) M. Dokmanovic and P. A. Marks, J. Cell. Biochem., 2005, 96, 293; (b) D. Demonte, V. Quivy, Y. Colette and C. Van Lint, Biochem. Pharmacol., 2004, 68, 1231-1238; (c) K. Shirakawa, L. Chavez, S. Hakre, V. Calvanese and E. Verdin, Trends Microbiol., 2013, 21, 277-285.

21 X. Contreras, M. Schweneker, C. S. Chen, J. M. McCune, S. G. Deeks, J. Martin and B. M. Peterlin, J. Biol. Chem., 2009, 284, 6782-6789.

22 N. M. Archin, J. L. Kirchherr, J. A. M. Sung, G. Clutton, K. Sholtis, Y. Y. Xu, B. Allard, E. Stuelke, A. D. Kashuba, J. D. Kuruc, J. Eron, C. L. Gay, N. Goonetilleke and D. M. Margolis, J. Clin. Invest., 2017, 127, 3126-3135.

23 T. D. Zaikos, M. M. Painter, N. T. Sebastian, V. H. Terry and K. L. Collins, J. Virol., 2018, 02110-02117.

24 N. Sagotlerolle, A. Lamine, M. L. Chaix, F. Boufassa, J. P. Aboulker, D. Costagliola, C. Goujard, C. Pallier, C. Paller and J. F. Delfraissy, AIDS, 2008, 22, 1125-1129.

25 J. P. Routy, C. L. Tremblay, J. B. Angel, B. Trottier, D. Rouleau, J. G. Baril, M. Harris, S. Trottier, J. Singer, N. Chomont, R. P. Sekaly and M. R. Boulassel, HIV Med., 2012, 13, 291-296. 
26 N. M. Archin, R. Bateson, M. K. Tripathy, A. M. Crooks, K. H. Yang, N. P. Dahl, M. F. Kearney, E. M. Anderson, J. M. Coffin, M. C. Strain, D. D. Richman, K. R. Robertson, A. D. Kashuba, R. J. Bosch, D. J. Hazuda, J. D. Kuruc, J. J. Eron and D. M. Margolis, J. Infect. Dis., 2014, 210, 728735.

27 N. M. Archin, M. Cheema, D. Parker, A. Wiegand, R. J. Bosch, J. M. Coffin, J. Eron, M. Cohen and D. M. Margolis, PLoS One, 2010, 5, e9390.

28 S. Micheva-Viteva, Y. Kobayashi, L. C. Edelstein, A. L. Pacchia, H. L. Lee, J. D. Graci, J. Breslin, B. D. Phelan, L. K. Miller, J. M. Colacino, Z. Gu, Y. Ron, S. W. Peltz and J. P. Dougherty, J. Biol. Chem., 2011, 286, 21083-21091.

29 G. M. Laird, C. K. Bullen, D. I. Rosenbloom, A. R. Martin, A. L. Hill, C. M. Durand, J. D. Siliciano and R. F. Siliciano, J. Clin. Invest., 2015, 125, 1901-1912.

30 E. D. Crignis and T. Mahmoudi, Viruses, 2014, 6, 4581-4608.

31 M. Purwin, J. Hernández-Toribio, C. Coderch, R. Panchuk, N. Skorokhyd, K. Filipiak, B. de Pascual-Teresa and A. Ramos, $R S C$ Adv., 2016, 6, 66595-66608.

32 X. Chen, S. Zhao, Y. Wu, Y. Chen, T. Lu and Y. Zhu, RSC Adv., 2016, 6, 103178-103184.

33 (a) A. K. Halder, S. Mallick, D. Shikha, A. Saha, K. D. Saha and T. Jha, RSC Adv., 2015, 5, 72373-72386; (b) X. Zhang, J. Zhang, M. Su, Y. Zhou, Y. Chen, J. Li and W. Lu, RSC Adv., 2014, 4, 40444-40448.

34 A. Petrelli and G. Valabrega, Expert Opin. Pharmacother., 2009, 10, 589-600.

35 K. S. Keedy, N. M. Archin, A. T. Gates, A. Espeseth, D. J. Hazuda and D. M. Margolis, J. Virol., 2009, 83, 47494756.

36 E. Bourguet, K. Ozdarska, G. Moroy, J. Jeanblanc and M. Naassila, J. Med. Chem., 2018, 61, 1745-1766.

37 K. Abouzid and S. Shouman, Bioorg. Med. Chem., 2008, 16, 7543-7551.

38 J. A. Joule, K. Mills and G. F. Smith, Quinolines and isoquinolines: reactions and synthesis, Heterocyclic Chemistry, 1995, pp. 120-145.

39 X. Q. Wang, C. L. Xia, S. B. Chen, J. H. Tan, T. M. Ou, S. L. Huang, D. Li, L. Q. Gu and Z. S. Huang, Eur. J. Med. Chem., 2015, 89, 349-361.

40 E. Pitta, M. K. Rogacki, O. Balabon, S. Huss, F. Cunningham, E. M. Lopez-Roman, J. Joossens, K. Augustyns, L. Ballell, R. H. Bates and P. Van der Veken, J. Med. Chem., 2016, 59, 6709-6728.

41 V. S. Gopinath, J. Pinjari, R. T. Dere, A. Verma, P. Vishwakarma, R. Shivahare, M. Moger, P. S. Kumar Goud, V. Ramanathan, P. Bose, M. V. Rao, S. Gupta,
S. K. Puri, D. Launay and D. Martin, Eur. J. Med. Chem., 2013, 69, 527-536.

42 H. Cope, R. Mutter, W. Heal, C. Pascoe, P. Brown, S. Pratt and B. Chen, Eur. J. Med. Chem., 2006, 41, 1124-1143.

43 Y. Wu, W. Dai, X. Chen, A. Geng, Y. Chen, T. Lu and Y. Zhu, RSC Adv., 2017, 7, 52180-52186.

44 A. Jordan, D. Bisgrove and E. Verdin, EMBO J., 2003, 22, 1868-1877.

45 Y. K. K., R. Pearson, J. Hokello, K. Lassen, J. Friedman, M. Tyagi and J. Karn, J. Virol., 2008, 82, 12291-12303.

46 V. T. Nguyen, T. Kiss, A. A. Michels and O. Bensaude, Nature, 2001, 414, 322-325.

47 Z. Li, J. Guo, Y. Wu and Q. Zhou, Nucleic Acids Res., 2013, 41, 277-287.

48 P. G. Mccaffrey, C. Luo, T. K. Kerppola, J. Jain, T. M. Badalian, A. M. Ho, E. Burgeon, W. S. Lane, J. N. Lambert and T. Curran, Science, 1993, 262, 750-754.

49 D. D. Richman, D. M. Margolis, M. Delaney, W. C. Greene, D. Hazuda and R. J. Pomerantz, Science, 2009, 323, 13041307.

50 J. H. N. Yik, R. C. Chen, R. Nishimura, J. L. Jennings, A. J. Link and Q. Zhou, Mol. Cell, 2003, 12, 971-982.

51 Z. Yang, Q. Zhu, K. Luo and Q. Zhou, Nature, 2001, 414, 317322.

52 C. Jeronimo, D. Forget, A. Bouchard, Q. Li, G. Chua, C. Poitras, C. Thérien, D. Bergeron, S. Bourassa and J. Greenblatt, Mol. Cell, 2007, 27, 262-274.

53 B. J. Krueger, C. Jeronimo, B. B. Roy, A. Bouchard, C. Barrandon, S. A. Byers, C. E. Searcey, J. J. Cooper, O. Bensaude and É. A. Cohen, Nucleic Acids Res., 2008, 36, 2219-2229.

54 B. Sobhian, N. Laguette, A. Yatim, M. Nakamura, Y. Levy, R. Kiernan and M. Benkirane, Mol. Cell, 2010, 38, 439-451.

55 J. E. Brogie and D. H. Price, Nucleic Acids Res., 2017, 45, 68646880.

56 J. Wu, M. T. Ao, R. Shao, H. R. Wang, D. Yu, M. J. Fang, X. Gao, Z. Wu, Q. Zhou and Y. H. Xue, Sci. Rep., 2017, 7.

57 N. He, N. S. Jahchan, E. Hong, Q. Li, M. A. Bayfield, R. J. Maraia, K. Luo and Q. Zhou, Mol. Cell, 2008, 29, 588599.

58 Y. H. Xue, Z. Y. Yang, R. C. Chen and Q. Zhou, Nucleic Acids Res., 2010, 38, 360-369.

59 Z. Y. Yang, J. H. N. Yik, R. C. Chen, N. H. He, M. K. Jang, K. Ozato and Q. Zhou, Mol. Cell, 2005, 19, 535-545.

60 N. H. He, M. Liu, J. Hsu, Y. H. Xue, S. Chou, A. Burlingame, N. J. Krogan, T. Alber and Q. Zhou, Mol. Cell, 2010, 38, 428438. 